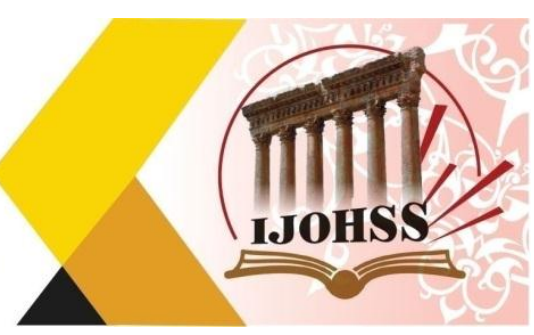

\title{
إبراز هوية زخارف التراث السعودي بالتصميم والتطريز الآلي على مكملات الملابس بالئس
}

\author{
د. نوره محسن محمد الاعجاني \\ قسم تصميم الأزياء والنسيج مديج \\ كلية التصاميم والفنون التطبيقية \\ جامعة الطائف \\ المملكة العربية السعودية الطروية \\ البريد الأكتروني: nora.m@ tu.edu.sa
}

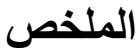

تميزت المملكة العربية السعودية بتراث زاخر يمند في مختلف أنحاء المملكة ليؤكد هويتها وأصالتها بما تحمله من تاريخ وتراث معماري غني، وما يحوي من رسومات زخارف تقليدية ذات سيمات تر اثثية مختلفة و هي منتشر بمختلف مناطقها، تجمعها وحدة طابع تراثي يعكس جوانب حضارية من تاريخ الأمة، فيبرز الموروث في جوانب عديدة ( حضارية ومعمارية و علمية وثقافية ) 1، ولزخارف التراث السعودي داورا هاما في مجال البحث العلمي حيث انه غني بالتفاصيل الدقيقة والتي تعبر عن فترات زمنية مختلفة يمكن من خلالها احياء هذا التراث بعد الاف السنين، هدف البحث إلى ابتكار تصميمات مستوحاة من زخارف التراث السعودي على مكملات الملابس(الحزام ، الثال ، الكمامة) وتنفيذها بأسلوب التطريز الآلي، وقد كانت مشكلة البحث ما

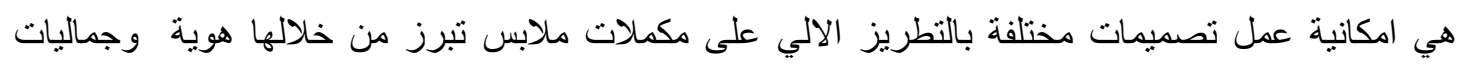

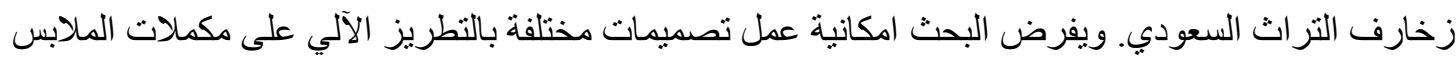
لإبر از هوية التراث السعودي، نتائج البحث ان زخارف النراث السعودي المطرزة اضافة قيمة جمالية ووظيفية على مكملات الملابس ، ويوجد فروق دالة إحصائيا بين التصميمات المنتجة بالبحث عند مستوي دلالة 0.01

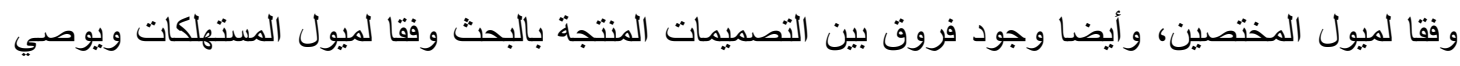
البحث بالمساهمة في الحفاظ على التراث السعودي بجميع أثكاله وتتو عه وابرازه من خلال الملابس ومكملاتها في المحافل المحلية و العالمية والسعي في تسويق المنتجات الملبسية المطرزة التي تعكس هوية التراث السعودي ونسي. 


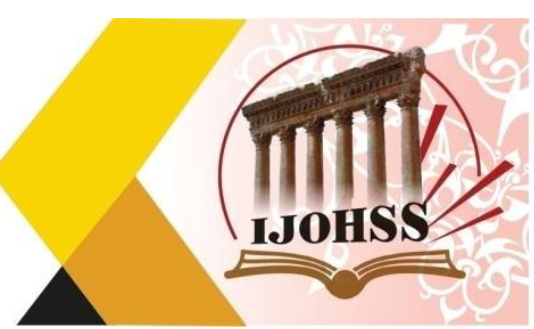

\title{
Highlighting The Identity of The Saudi Heritage Motifs by Designing and Machine Embroidery on Clothing Accessories
}

\author{
Dr. Nora Mohsen Mohammed Dajani \\ Department of Fashion and Textile Design \\ College of Design and Applied Arts \\ Taif University \\ Kingdom Saudi Arabia \\ Email: nora.m@tu.edu.sa
}

\begin{abstract}
The Kingdom of Saudi Arabia has been distinguished by a rich heritage that extends throughout the Kingdom to confirm its identity and originality, with its rich architectural history and heritage, and what contains authentic heritage, ornaments and traditional drawings with different heritage features and is spread in its various regions, united by a heritage character that reflects civilized aspects of the nation's history. The heritage is highlighted in many aspects (civilized, architectural, scientific, and cultural), the Saudi heritage has an identity that is replete with different features and includes arts and decorations that differ according to its regions. This heritage after thousands of years, the research aimed to create designs inspired by the motifs of the Saudi heritage on clothing accessories (belt, shawl, muzzle) and implement them in the style of machine embroidery, and the research problem was what is the possibility of making different designs with machine embroidery on clothing supplements through which an identity emerges Saudi heritage. The research imposes the possibility of making different designs with automatic embroidery on clothing accessories to highlight the identity of the Saudi heritage. The results of the research are that there are statistically significant differences between the designs produced in the research at a significance level of 0.01 according to the opinions of specialists, and also that there are differences between the designs produced in the research according to the tendencies of consumers, and the research recommends contributing to the preservation On the Saudi heritage in all its forms and diversity, highlighting it through clothing and its accessories in local and international forums, and endeavoring to market embroidered clothing products that reflect the identity of the Saudi heritage.
\end{abstract}

Keywords: Hand embroidery, traditional fashion, small production project. 


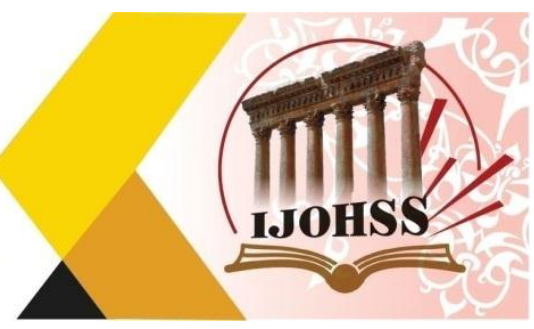

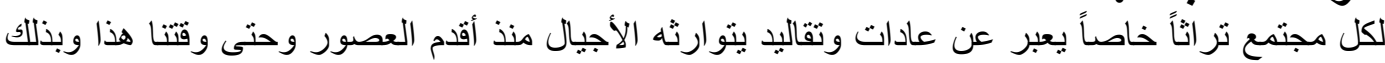

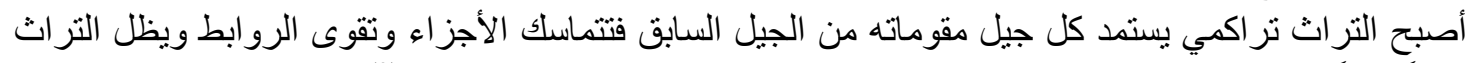

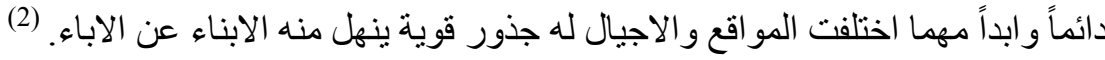

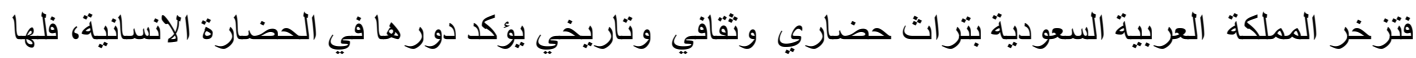

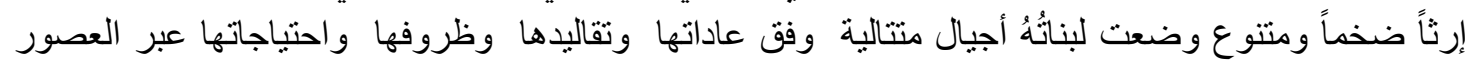

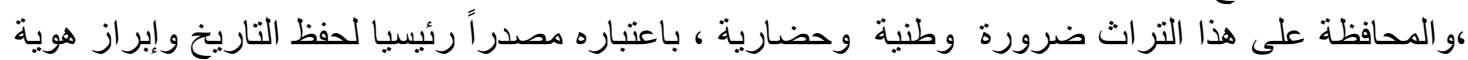

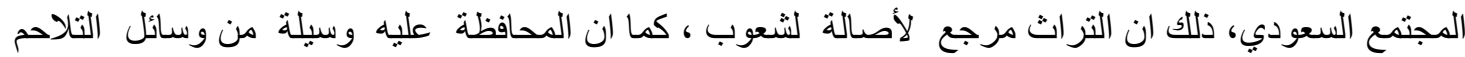

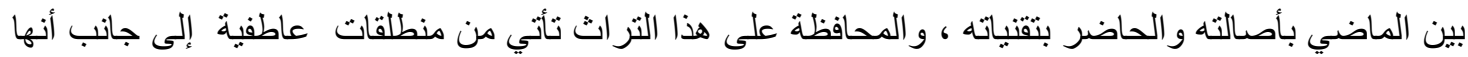

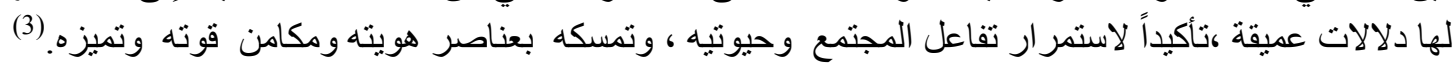

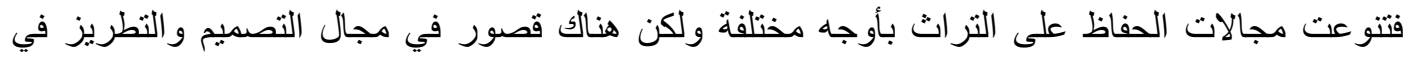

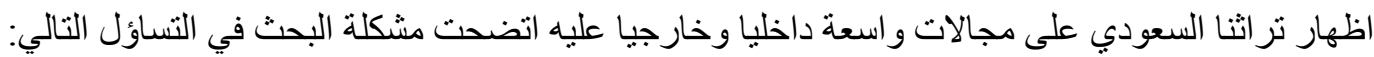
1. كيف يمكن ابراز هوية التراث السعودي من خلالها مكات مكملات الملابس.

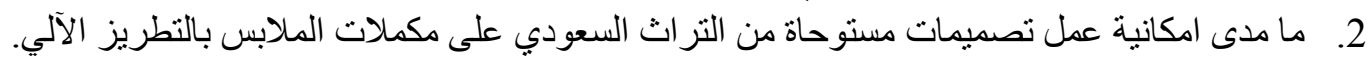
الأهداف:

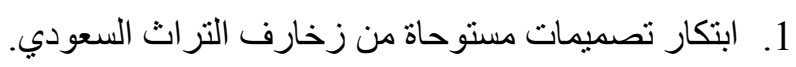

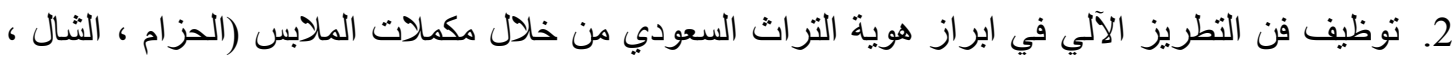

3. السعي في الحفاظ على هوية التراث السعودي وابر ازه في المحافل و المهرجانات المحلية والعالمية.

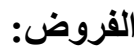

1. يمكن عمل تصميمات مستوحاة من هوية التراث السعودي على مكملات الملابس بأسلوب التطريز الآلي.

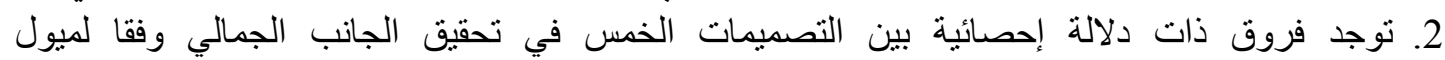

3. توجد فروق ذات دلالة إحصائية بين التصميمات الخمس في تحقيق الجانب الوظيفي وفقا لميول

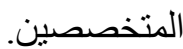

4. توجد فروق ذات دلالة إحصائية بين التصميمات الخمس وفقا لأر اء المستهكات.

1. المساهمة في الحفاظ على هوية التراث السعودي من خلال ابرازه بفن التطريز الالي على مكملات الملابس العابس

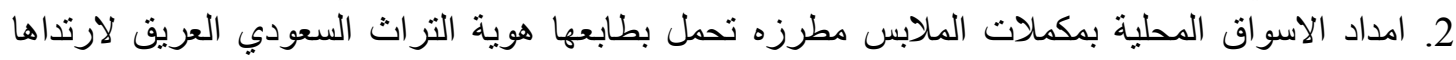

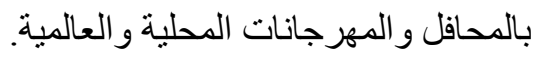

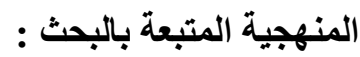

يتبع البحث المنهج الوصفي والتبهي التبيقي من خلال دراسة التراث السعودي ودر اسة فن التطريز الآلي وامكانية

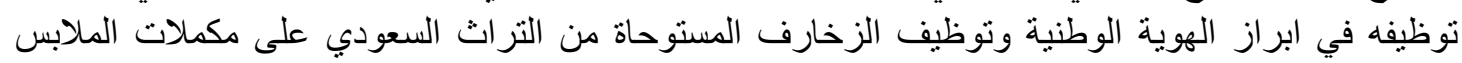
باستخدام التطريز الالي. 


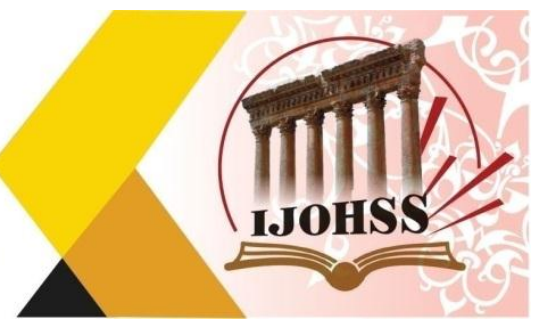

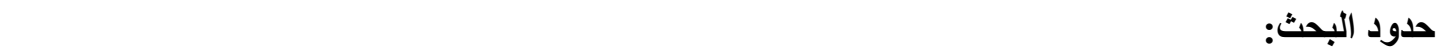

ترتكز حدود البحث على عمل مكملات ملابس مناسبة تبرز هوية وجماليات التراث الحضاري السعودي من

مختلف مناطق المملكة.

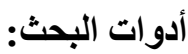

مجمو عات من التصميمات المنفذة من زخارف التراث السعودي بالتطريز الآلي على مكملات الملابس .

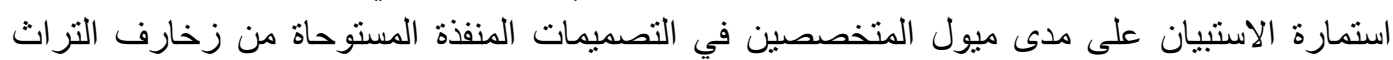

السعودي

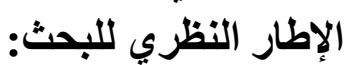

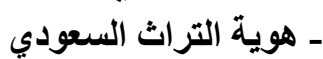

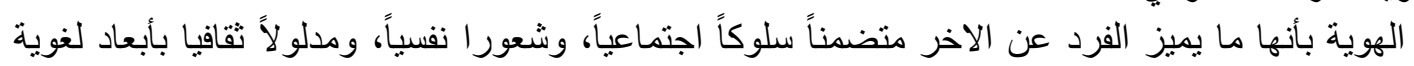

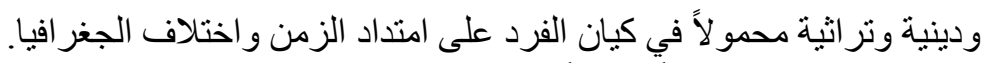

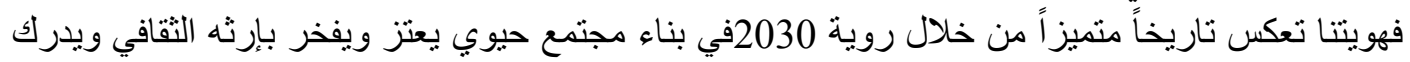

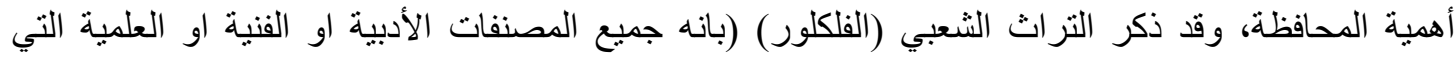

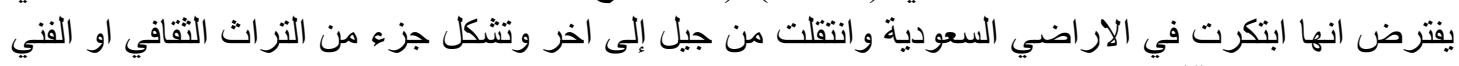

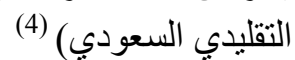

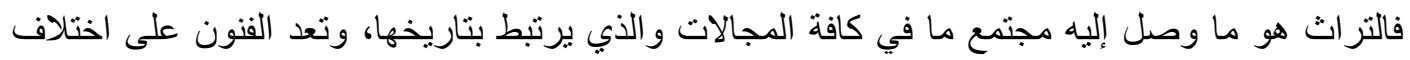

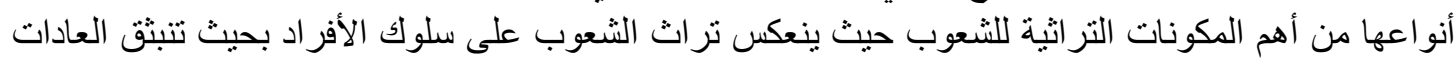

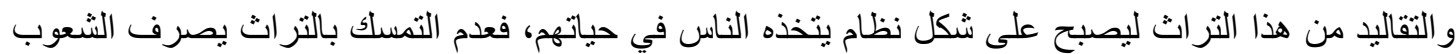

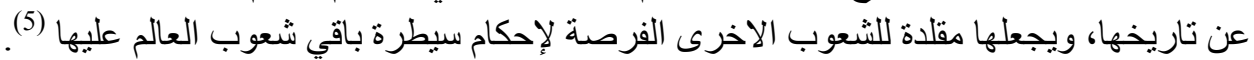

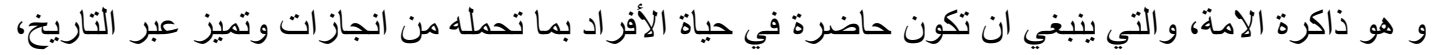

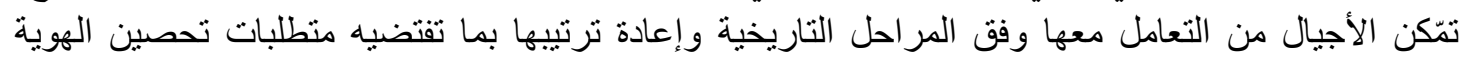

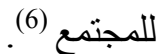
ويعد التراث عنصر اً اصيل من عناصر الثقافة ومعبر اساسي عن الهوية الوطنية ويعد ارثاً حضارياً متميزاً،

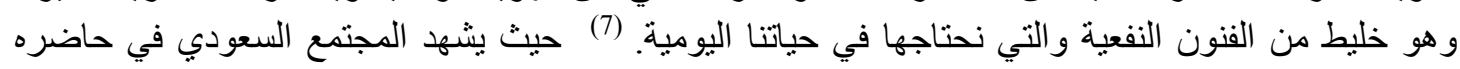
النمو و التطور على جميع الأصعدة لان هذا المجتمع ذو جذور عريقة ولديه إرث عظيم فمع مو اكبة العصر يجب الفي

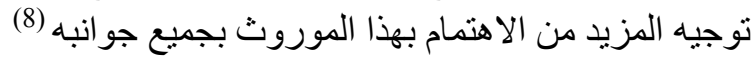

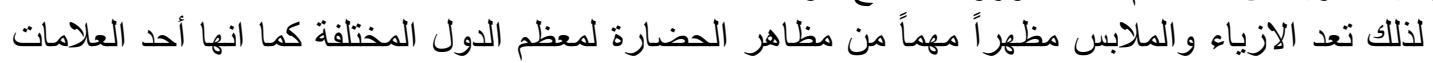

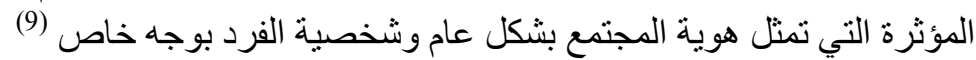
التطريز الآلي: - التي

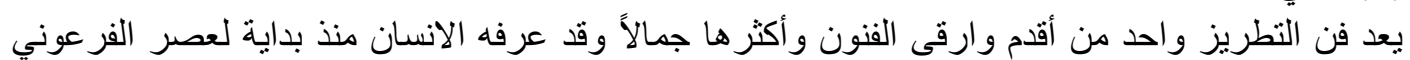

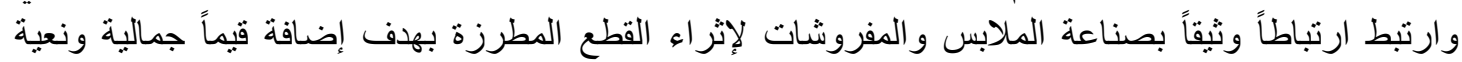
و اقتصادية (10).

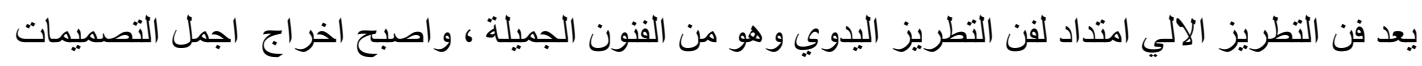

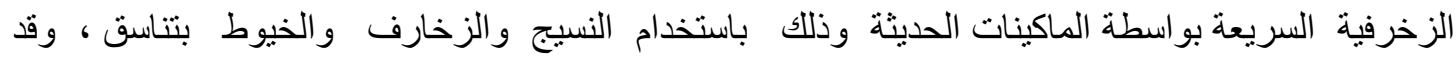

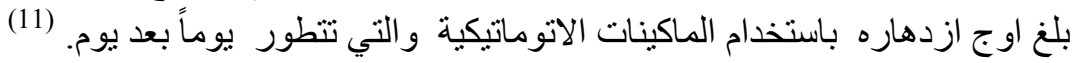




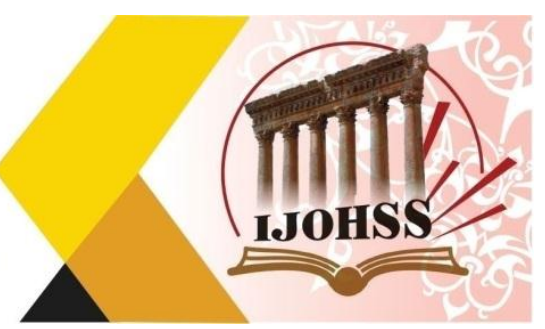

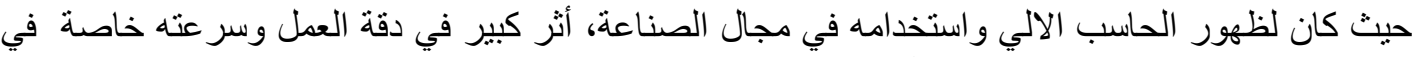

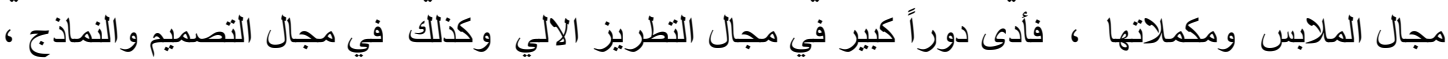

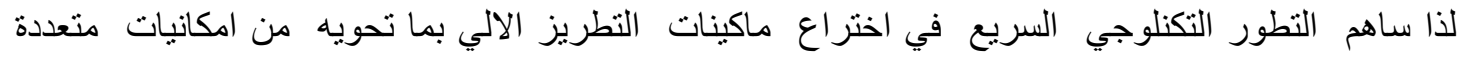

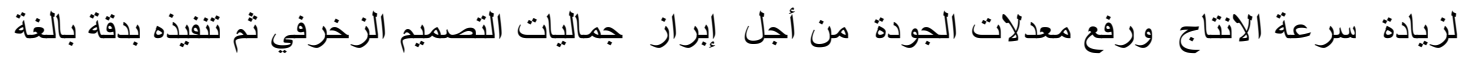

ارتبطت نشأة التزين بالرغبة الفطرية للإنسان البدائي في التجميل وإضافة بعض التباء اللمسات الجمالية لتزيين

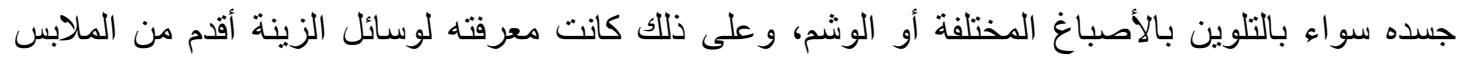

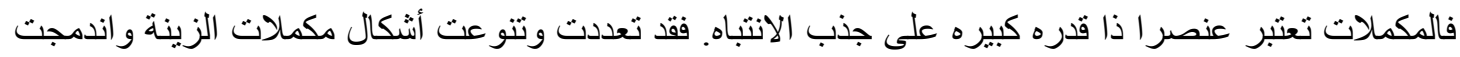

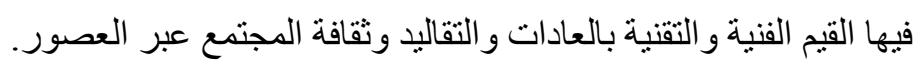

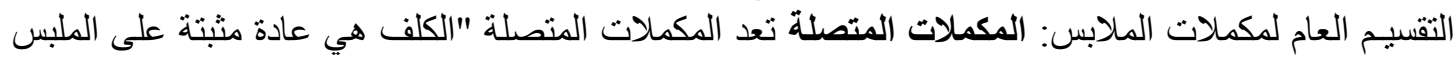

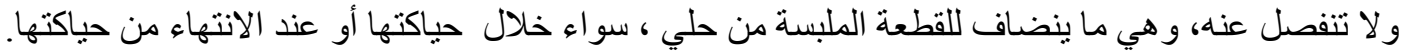

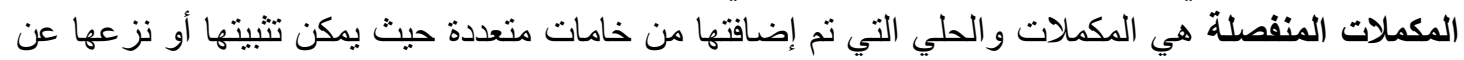

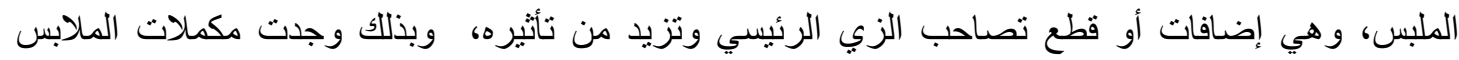

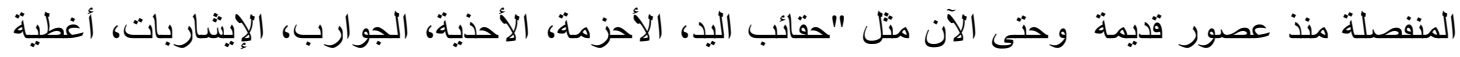

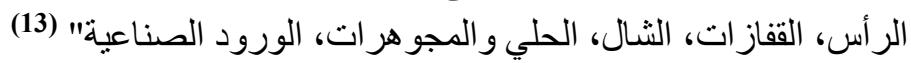

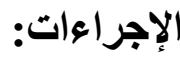
يتبع هذا البحث عدة اجر اءوات:

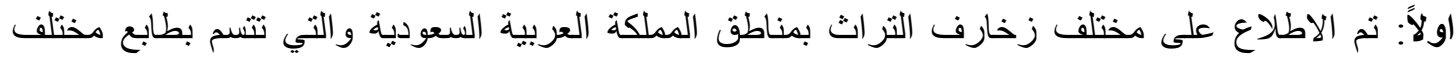

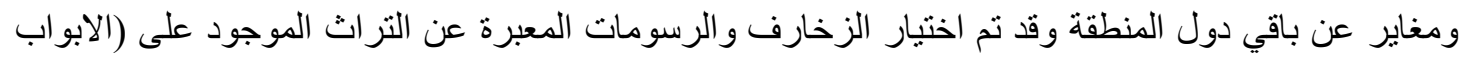
ـ النو افذ ـ الجداريات) للمناطق التالية:

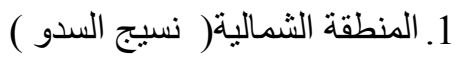

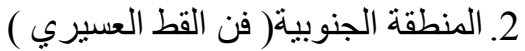
3. المنطقة الثرقية(جصية المباني بالأحساء ) 4. المنطقة الوسطى نجد (الأبواب النجدية ) 5. المنطقة الغربية الحجاز (الرواشين )

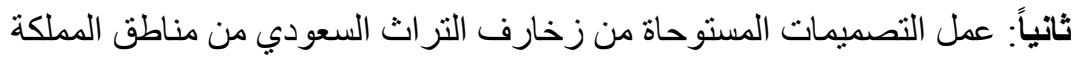

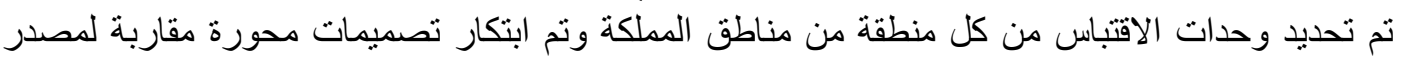

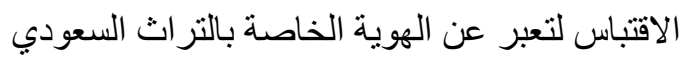

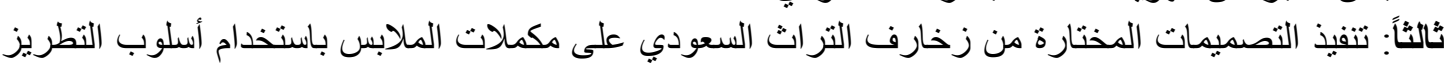
تم تحديد مكملات الملابس (الحز ام، و الثنال، و الكمامة) كمكمل ظاهر يحمل هوية التراث السعودي ويضفي على الملبس الجمالية والتميز و التقرد.

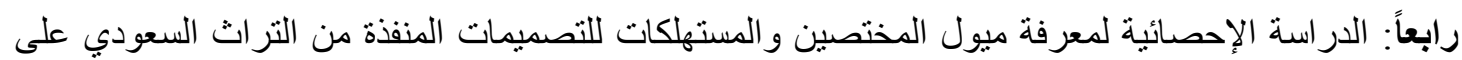
مكملات الملابس (الحزام، الثشال، الكمامة) 


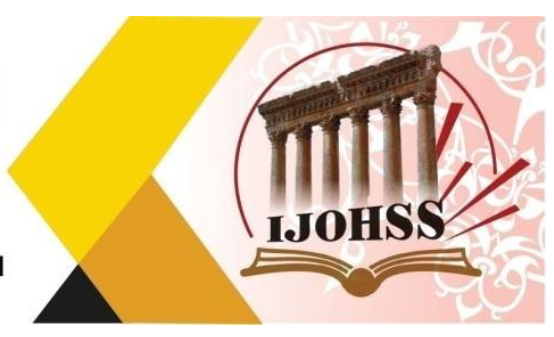

$$
\text { استعر اض النتائج: تم عرض النتائج من خلال فروض البحث. }
$$

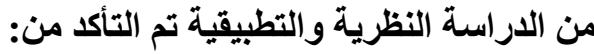

الفرض الأول الأي ينص: مدى أمكانية عمل تصميمات مستوحاة من هوية التراث السعودي على مكملات الملابس بأسلوب التطريز الآلي.

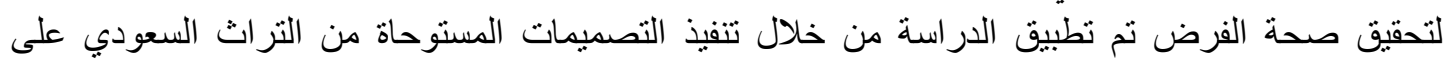
مكملات الملابس (الثال، الحزام، الكمامة) وفيما يلي عرض التصائل التصميمات المنفذة المستوحاة من التراث السعودي على مكملات الملابس بالتطريز الآلي. • التصميمات المنفذة من زخارف التراث بل السعودي ومصدر اقتباسها: جدول (1) التصميمات المنفذة من زخارف التراث السعودي على مكملات الملابس بالتطريز الالي

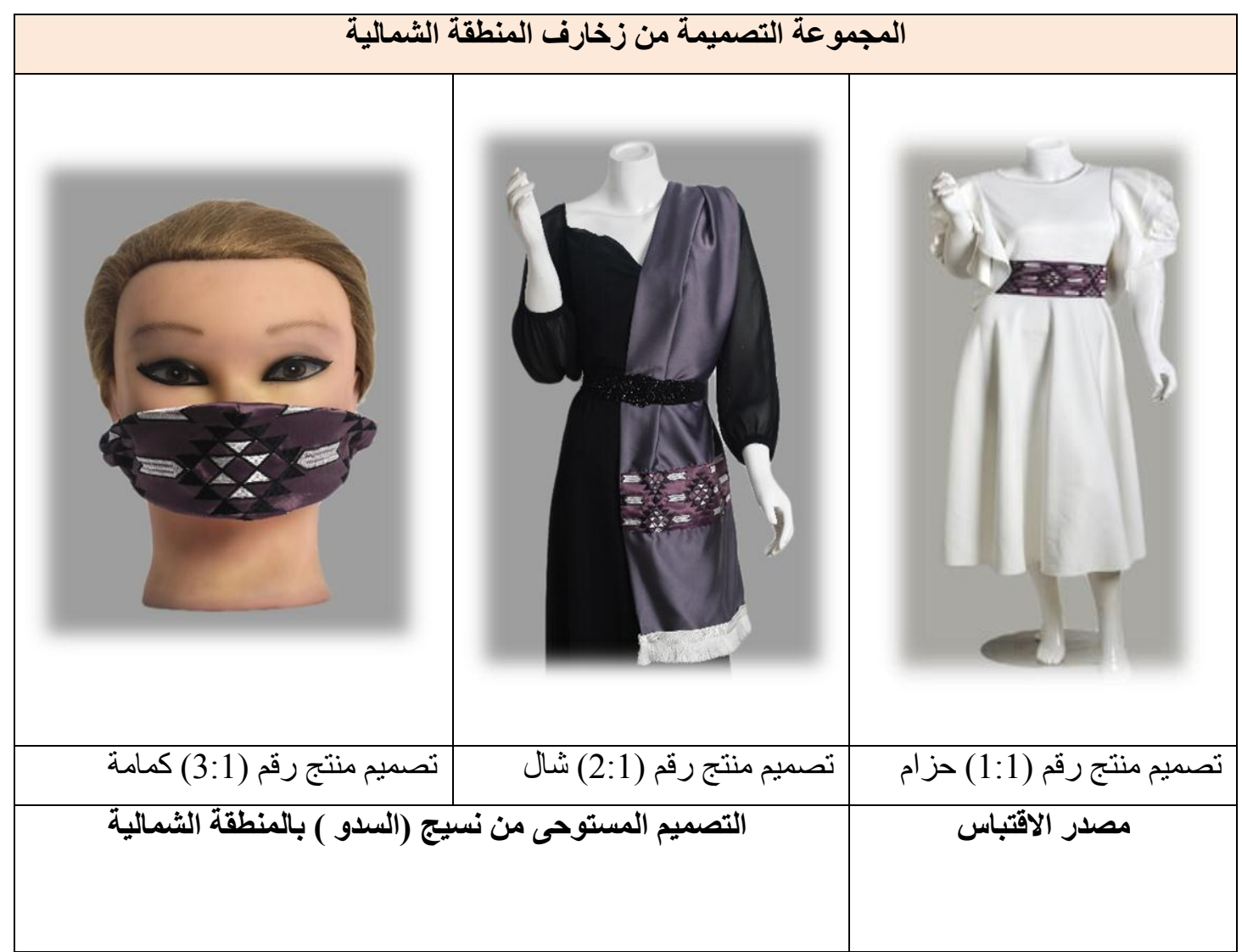


المجلة اللحولية اللملوم الآنسانية والامتماعية International Journal on Humanities and Social Sciences website:www.ijohss.com Email:editor@ijohss.com العدد (28) ديسمبر 2021 ISSN: 2415 - 4822

Volume (28) December 2021
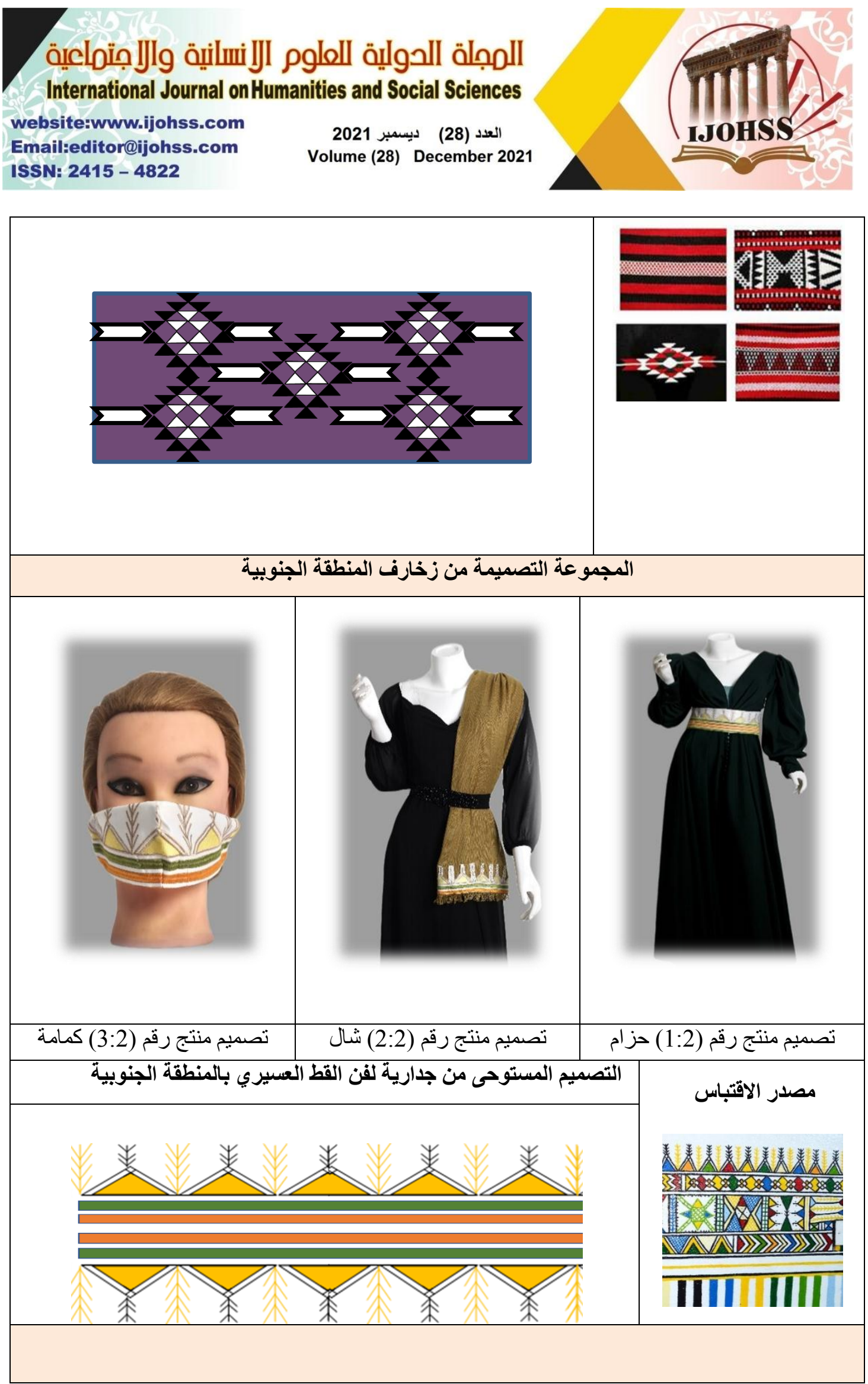
المبلة اللحولية اللملوم الآنسانية والإمتماعية International Journal on Humanities and Social Sciences website:www.ijohss.com Email:editor@ijohss.com العدد (28) ديسمبر 2021 ISSN: 2415 - 4822
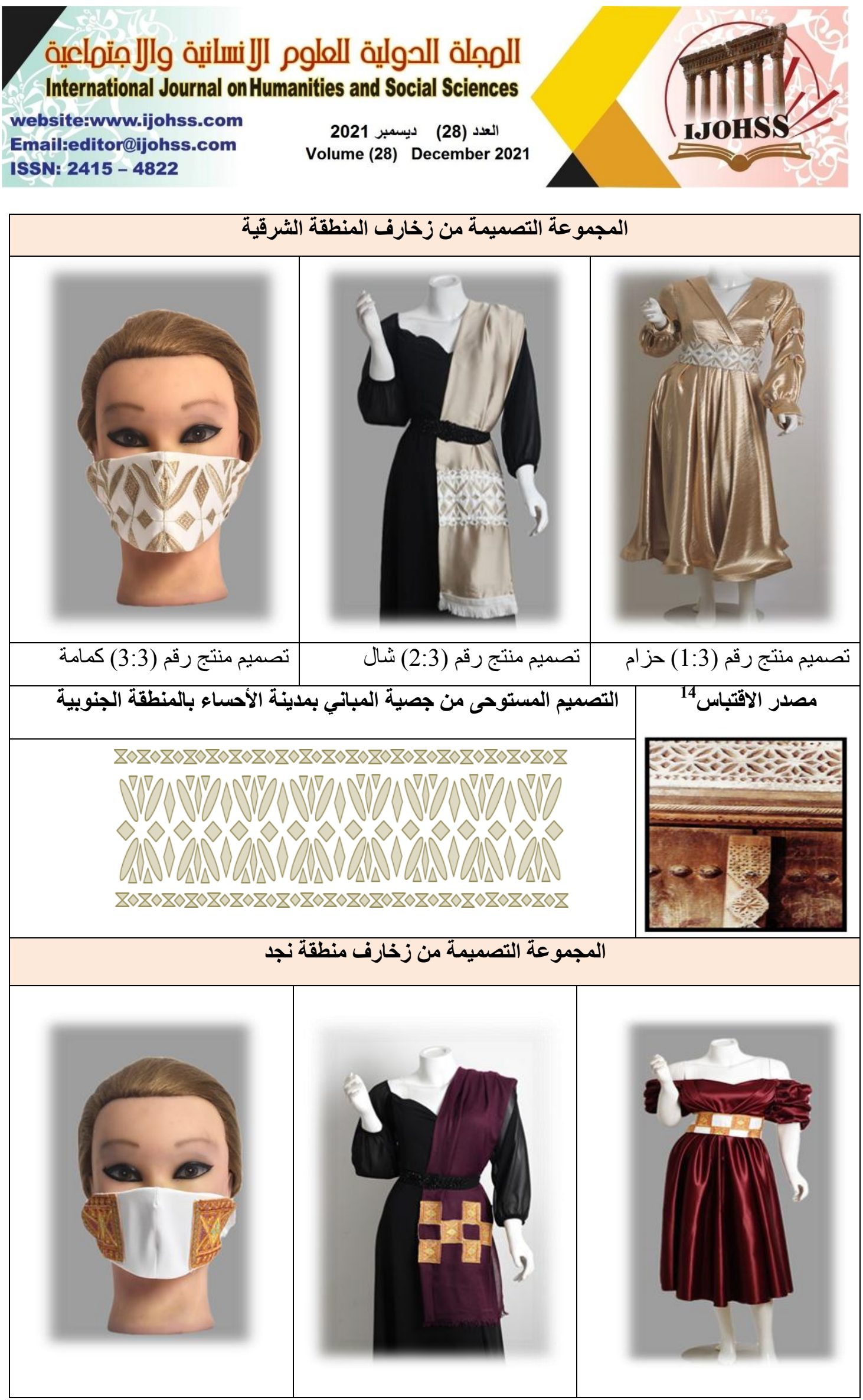
المبلة اللحولية اللملوم الآنسانية والإمتماعية International Journal on Humanities and Social Sciences website:www.ijohss.com Email:editor@ijohss.com العدد (28) ديسمبر 2021 ISSN: 2415 - 4822

Volume (28) December 2021

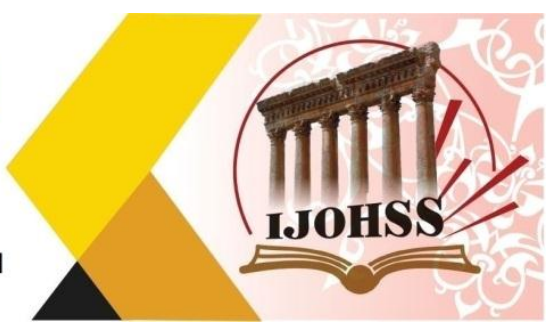

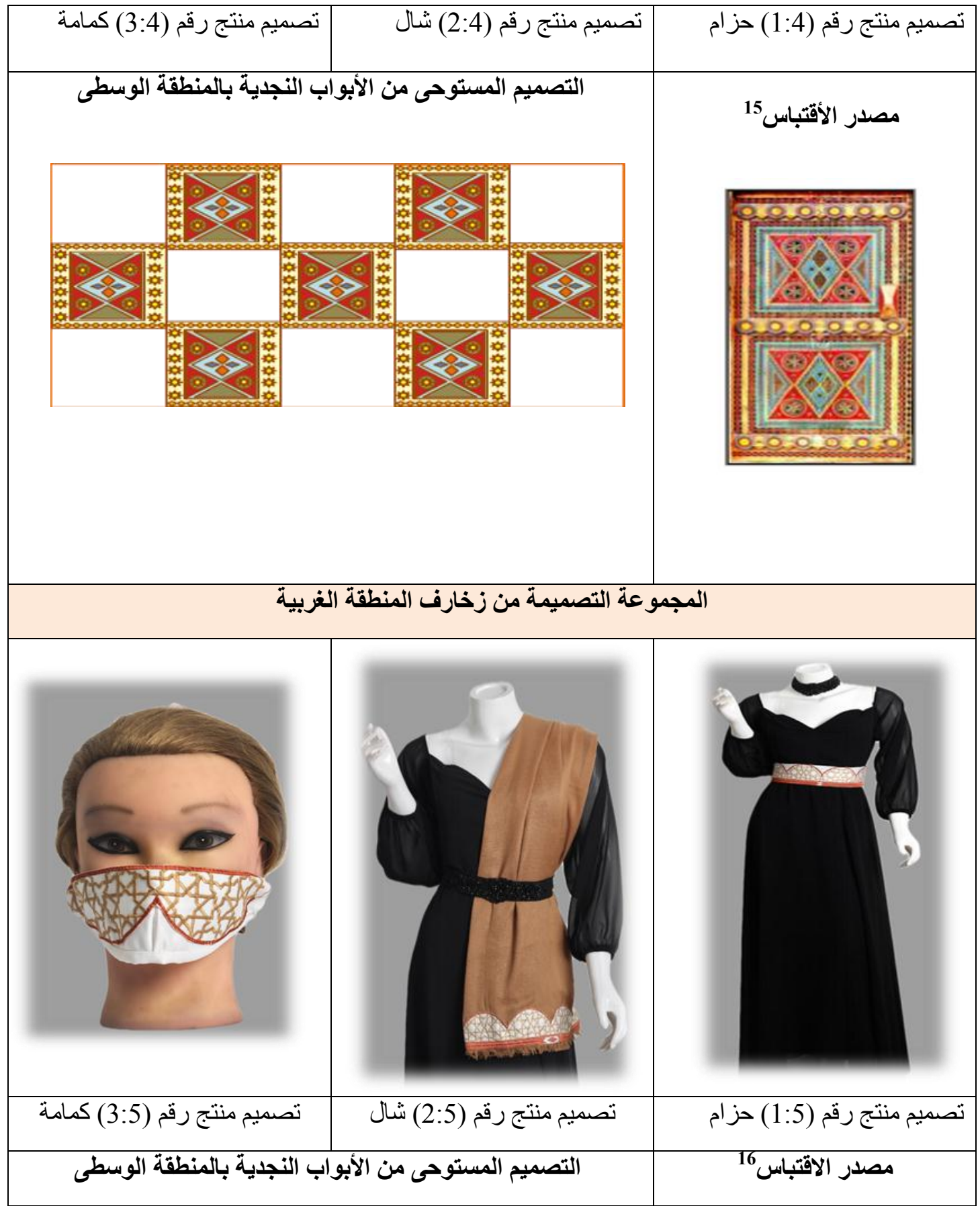



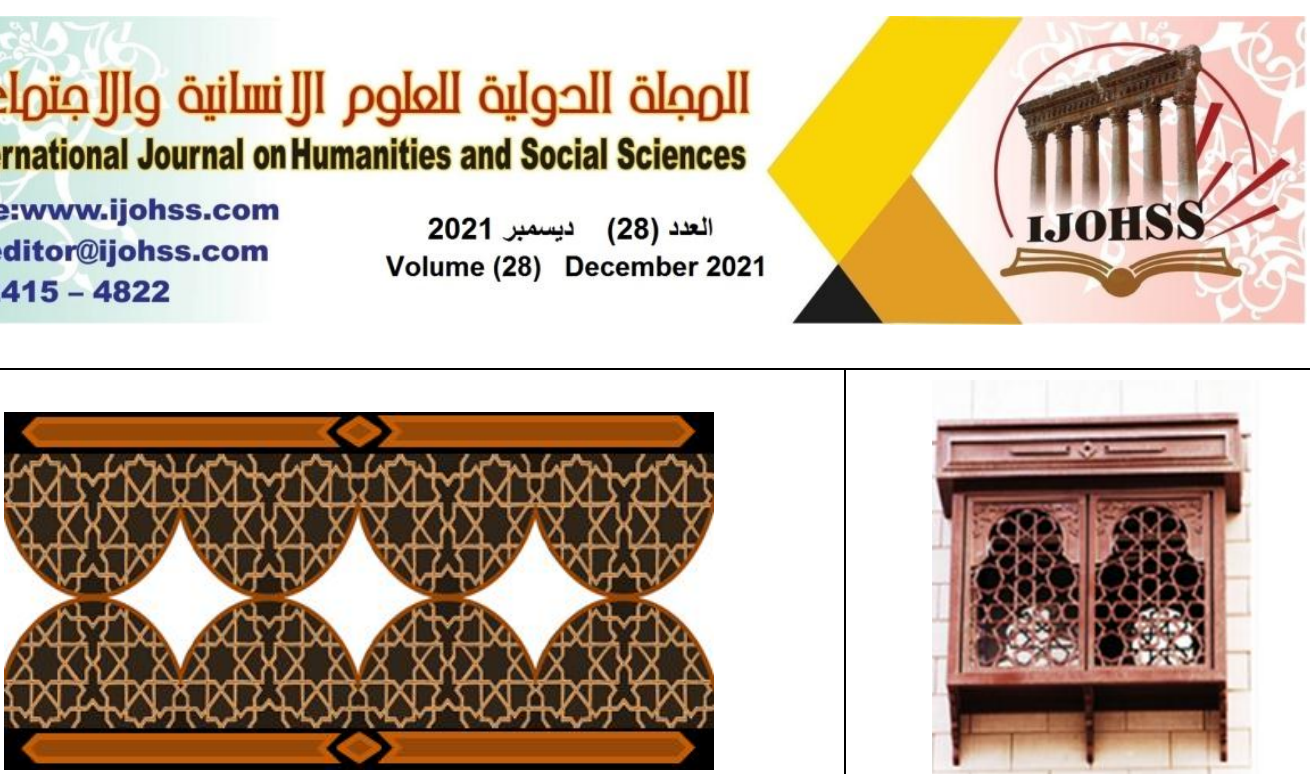

• من الار اسة الاحصائية تم عمل: اولاً: استبيان تقييم المختصين للتصميمات المستوحاة من التراث السعودي على مكملات الملابس

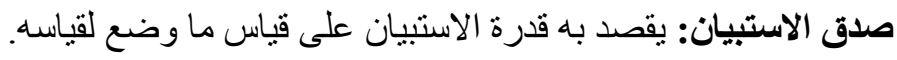

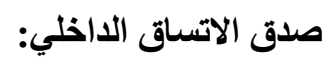

1- حساب معاملات الارتباط بين جميع المحاور ودرجة كل عبارة من العبارات بالمحور و الدرجة النهائية للمحور بالاستبيان.

2- حساب معاملات الارتباط بين الدرجة الكلية بالاستبيان و الدرجة الكلية لكل محور من محاور الاستبيان.

المحور الأول: الجانب الجمالي للتصميمات المنفذة بالتطريز الآلي المستوحاة من زخارف التراث السعودي:

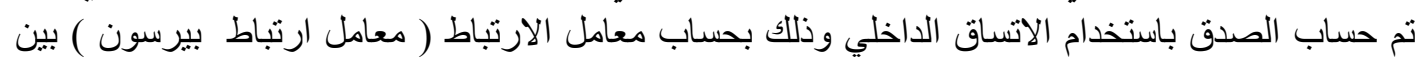

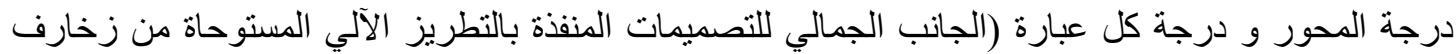

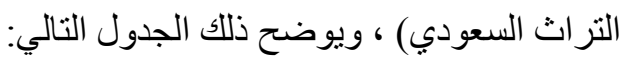

جدول ( 2) قيم معاملات الارتباط بين درجة كل عبارة ودرجة المحور (الجاتب الجمالي للتصميمات المنفذة

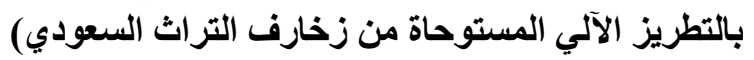

\begin{tabular}{|c|c|c|}
\hline الالالة & الارتباط & م \\
\hline 0.01 & $\overline{0.911}$ & 1 \\
\hline 0.01 & 0.735 & 2 \\
\hline 0.05 & 0.603 & 3 \\
\hline 0.01 & 0.826 & 4 \\
\hline
\end{tabular}

يتضح من الجدول أن معاملات الارتباط كلها دالة عند مستوى (0.01 - 0.05) لاقترابها من الواحد الصحيح مما يدل على صدق وتجانس عبار ات الاستبيان.

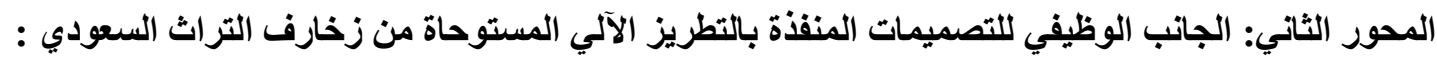

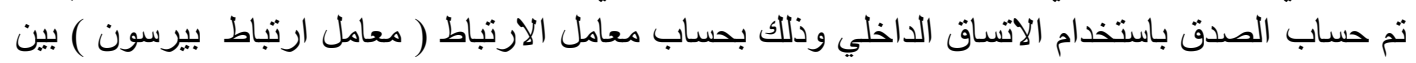
درجة كل عبارة ودرجة المحور (الجانب الوظيفي للتصميمات المنفذة بالتطريز الآلي المستوحاة من زخارف التبات

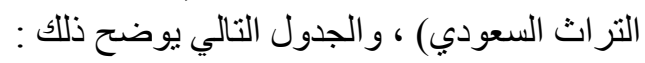
جدول (3) قيم معاملات الارتباط بين درجة كل عبارة ودرجة 


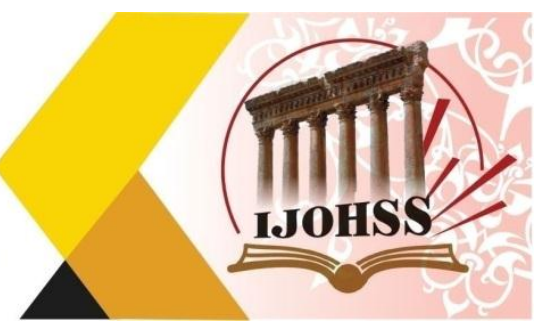

المحور (الجاتب الوظيفي للتصميمات المنفذة بالتطريز

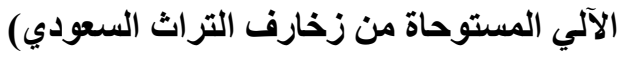

\begin{tabular}{|c|c|c|}
\hline الدلالة & الارتباط & م \\
\hline 0.05 & 0.641 & -1 \\
\hline 0.01 & 0.927 & -2 \\
\hline 0.01 & 0.752 & -3 \\
\hline 0.01 & 0.801 & -4 \\
\hline
\end{tabular}

يتضح من الجدول أن معاملات الارتباط كلها دالة عند مستوى (0.01 - 0.05) لاقتر ابها من الواحد الصحيح مما يدل

على صدق وتجانس عبار ات الاستنيان.

الصدق باستخدام الاتساق الألخي بين الدرجة الكلية لكل محور والدارجة الكلية للاستبيان:

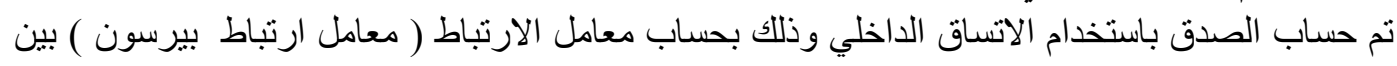

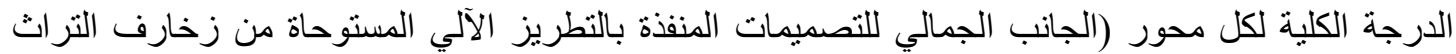

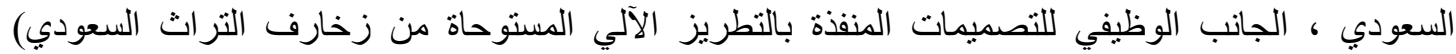

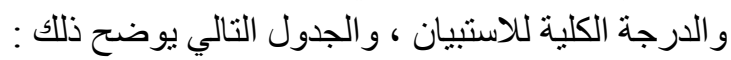

جدول (4 ) قيم معاملات الارتباط بين الارجة الكلية لكل محور و الدرجة الكلية للاستبيان

\begin{tabular}{|c|c|c|}
\hline الالالة & الارتباط & \\
\hline 0.01 & 0.726 & 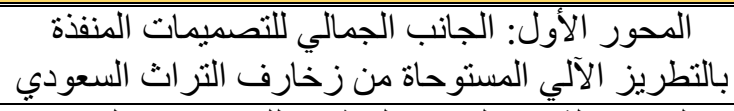 \\
\hline 0.01 & 0.811 & 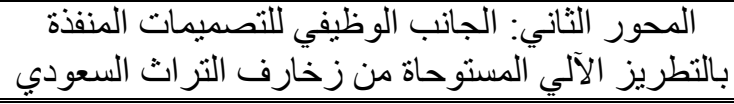 \\
\hline
\end{tabular}

يتضح من الجدول أن معاملات الارتباط كلها دالة عند مستوى (0.01) لاقتر ابها من الو احد الصحيح مما يدل على صدق وتجانس محاور الاستبيان . الثبات : الثيات

يقصد بالثبات reability دقة تطبيق القياس و الملاحظة ، و عدم تناقضه مع نفسه ، و واتساقه و واطر اده فيما

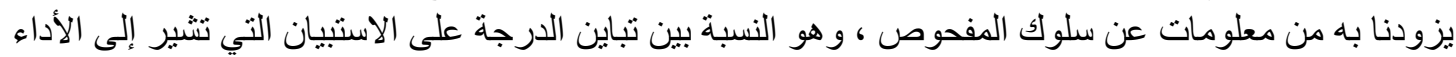

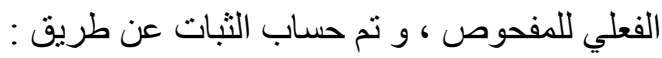

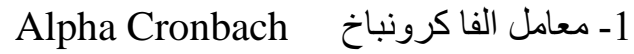

2- طريقة التجزئة النصفية

جدول ( 5 ) قيم معامل الثبات لمحاور استبيان المختصين

\begin{tabular}{|c|c|c|}
\hline التجزئة التصفية & معامل الفا & المحاور \\
\hline $0.952-0.887$ & 0.915 & 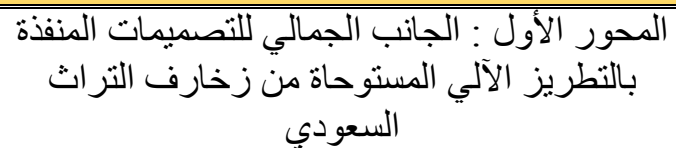 \\
\hline $0.791-0.726$ & 0.753 & 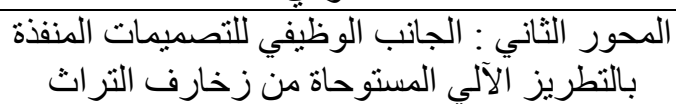 \\
\hline
\end{tabular}




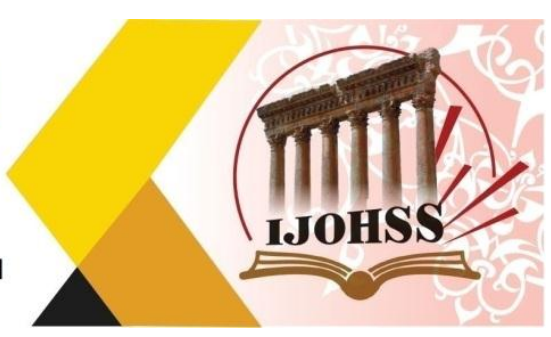

\begin{tabular}{|c|c|c|}
\hline & & السعودي \\
\hline $0.905-0.830$ & 0.861 & ثبات استبيان المختصين ككل \\
\hline
\end{tabular}

يتضح من الجدول السابق أن جميع قيم معاملات الثبات: معامل الفا، التجزئة النصفية دالة عند مستوى 0.01 مما يدل على ثبات الاستبيان. ثانياً: استبيان قياس مدى تقبل المستهلكات للتصميمات المستوحاة من التراث السعودي والمنفذة بالتطريز

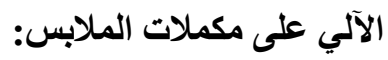

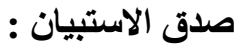

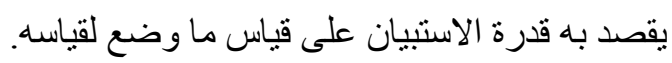

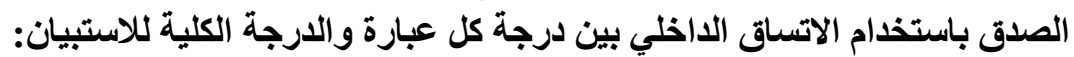

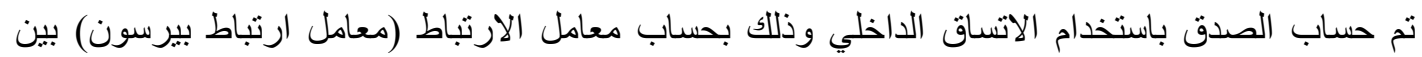

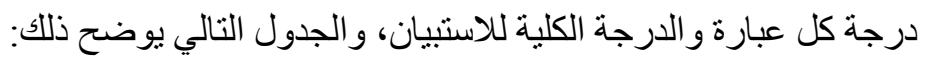
جدول ( 6 ) قيم معاملات الارتباط بين درجة كل عبارة والارجة الكلية للاستبيان

\begin{tabular}{|c|c|c|}
\hline الدلالة & الارتباط & م \\
\hline 0.01 & 0.853 & 1 \\
\hline 0.01 & 0.771 & 2 \\
\hline 0.05 & 0.628 & 3 \\
\hline 0.01 & 0.892 & 4 \\
\hline 0.01 & 0.701 & 5 \\
\hline 0.01 & 0.870 & 6 \\
\hline 0.05 & 0.634 & 7 \\
\hline 0.01 & 0.792 & 8 \\
\hline 0.05 & 0.611 & 9 \\
\hline 0.05 & 0.640 & 10 \\
\hline 0.01 & 0.909 & 11 \\
\hline 0.01 & 0.748 & 12 \\
\hline
\end{tabular}

يتضح من الجدول أن معاملين الارنباط كلها دالة عند مستوى (0.01، 0.05 ) لاقتر ابها من الواحد الصحيح مما يدل على صدق وتجانس عبار ات الاستبيان .

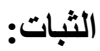

يقصد بالثبات reability دقة الاختبار في القياس و الملاحظة، و عدم تناقضه مع نفسه، و اتساقه و اطر اده فيما

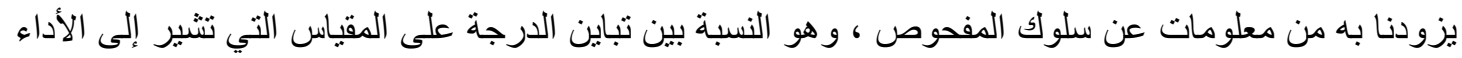

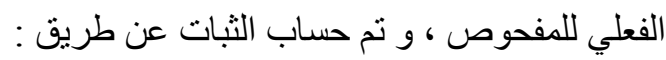
Alpha Cronbach يقاب

2- 2- طريقة التجزئة النصفية جدول ( 7 ) قيم معامل الثبات للاستبيان

\begin{tabular}{|c|c|c|}
\hline التجزئة النصفية & معامل الفا & \\
\hline $0.937-0.866$ & 0.891 & ثبات الاستبيان ككل \\
\hline
\end{tabular}




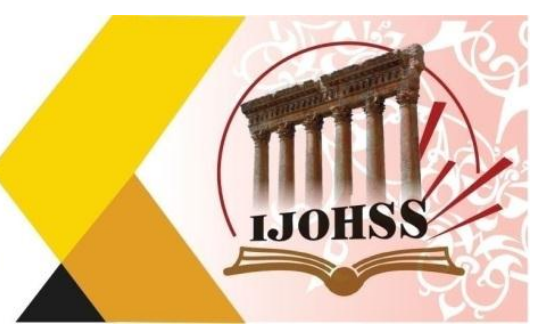

يتضح من الجدول السابق أن جميع قيم معاملين الثبات : معامل الفا ، التجزئة النصفية ، دالة عند مستوى 0.01 الفرض الثاني : توجد فروق ذات دلالة إحصائية بين التصميمات الخمس في تحقيق الجانب الجمالي وفقا

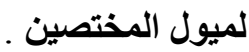
وللتحقق من هذا الفرض نم حساب تحليل التباين لمتوسط درجات التصميمات الخمس في تحقيق الجانب

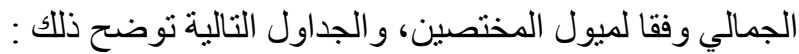
المجموعة الأولى: التصميمات المطرزة على مكمل ملبسي (حزام)

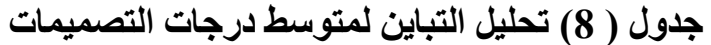

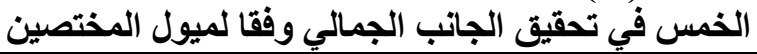

\begin{tabular}{|c|c|c|c|c|c|}
\hline الالالة & قيمة (ف) & درجات الحرية & متوسط المربعات & مجموع المربعات & الجاتب الجمالي \\
\hline \multirow{3}{*}{$\begin{array}{c}0.01 \\
\end{array}$} & \multirow{2}{*}{20.134} & 4 & 1717.009 & 696.035 & بين المجموعات \\
\hline & & 45 & 8.642 & 388.905 & داخل المجموعات \\
\hline & & 49 & & 1084.940 & المجموع \\
\hline
\end{tabular}

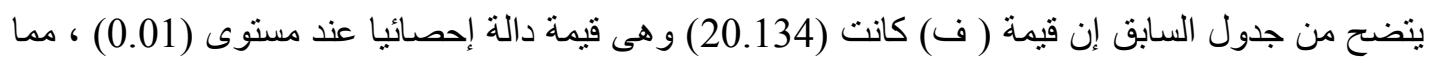

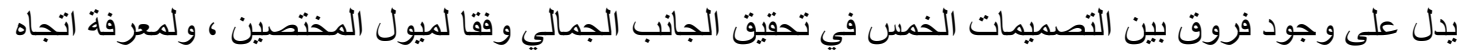

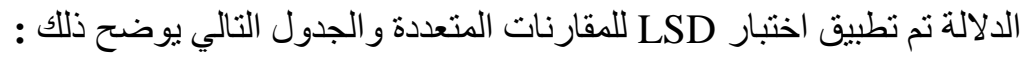

جدول ( 9 ) اختبار LSD للمقارنات المتعددة

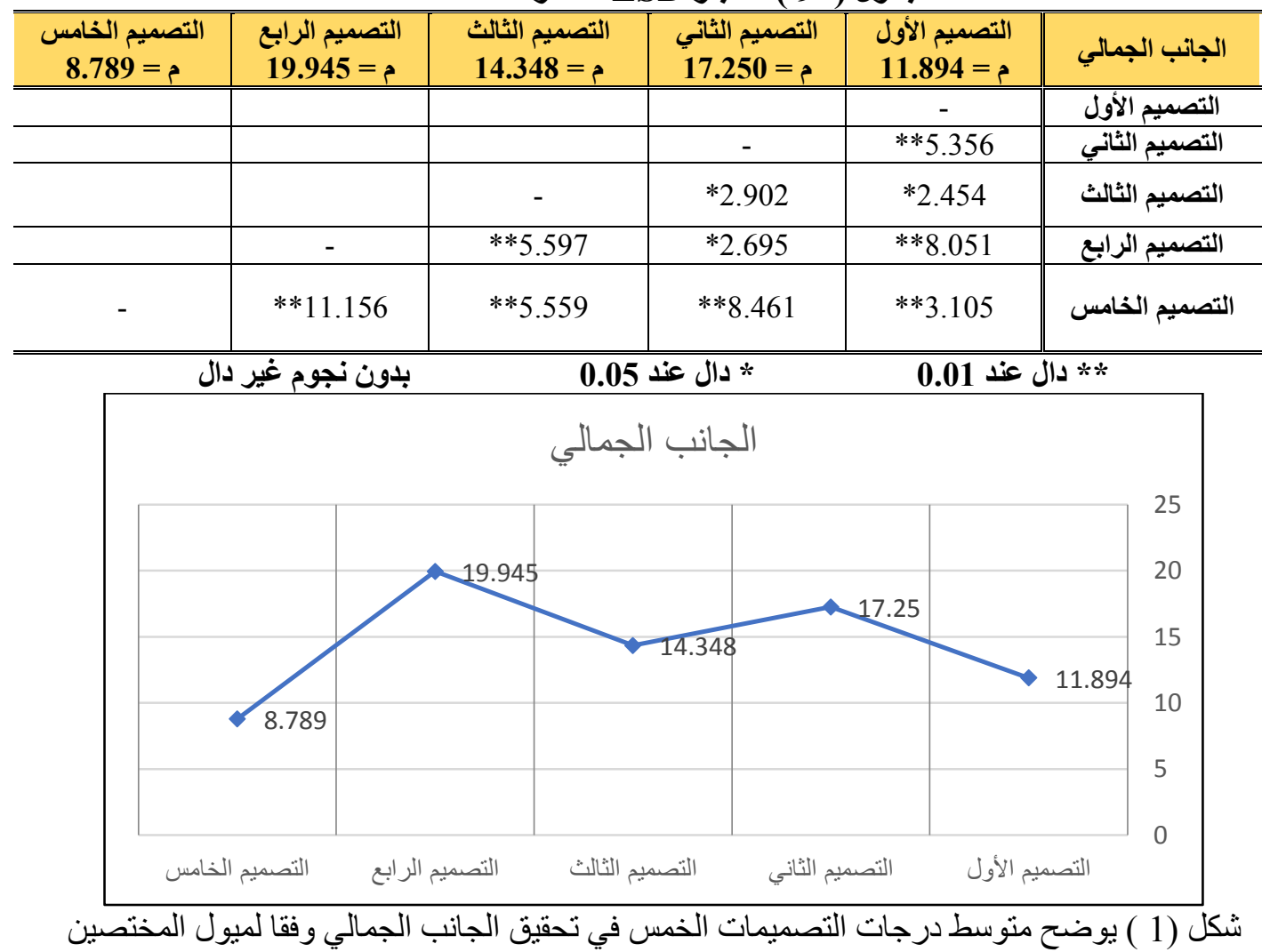




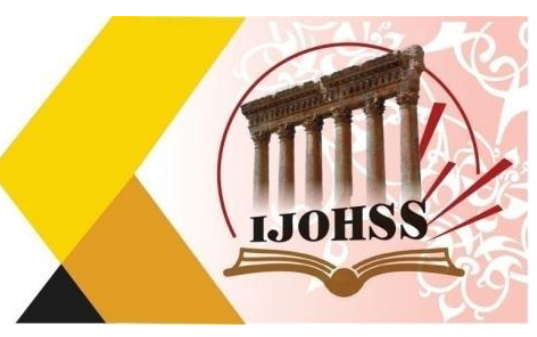

من الجدول ( 9) والثكل (1 1) يتضح أن :

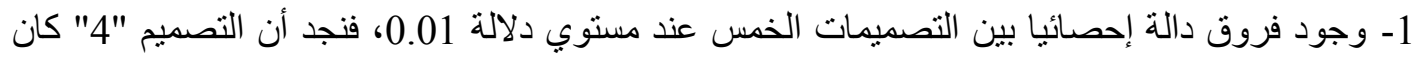

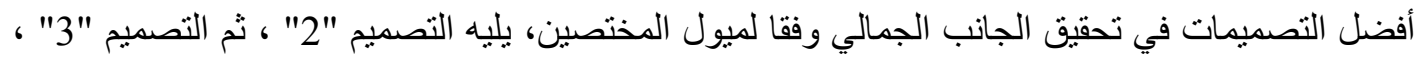

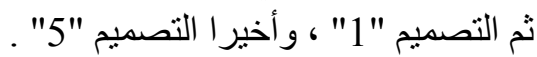

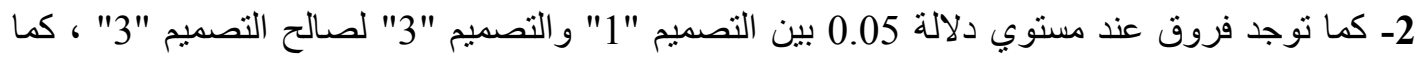

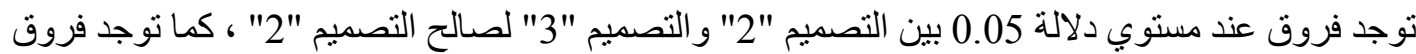

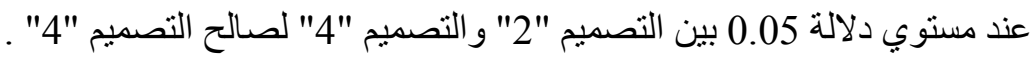
المجموعة الثانية : التصميمات المطرزة على مكمل ملبسي (الثال)

جدول ( 10) تحليل التباين لمتوسط درجات التصميمات

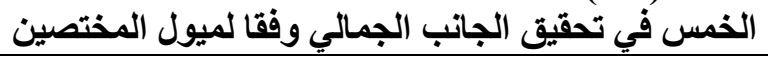

\begin{tabular}{|c|c|c|c|c|c|}
\hline الدالة & قيمة (ف) & درجات الحرية & متوسط المربعات & مجموع المربعات & الجاتب الجمالي \\
\hline \multirow{3}{*}{0.01} & \multirow[b]{2}{*}{63.663} & 4 & 254.982 & 1019.929 & بين المجموعات \\
\hline & & 45 & 4.005 & 180.233 & المجموعات \\
\hline & & 49 & & 1200.162 & المجموع \\
\hline
\end{tabular}

يتضح من جدول السابق إن قيمة ( ف) كانت (63.663) و هى قيمة دالة إحصائيا عند مستوى (0.01) ، مما

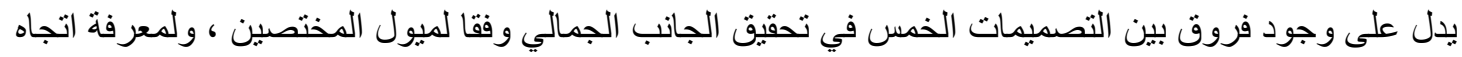

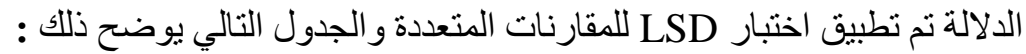

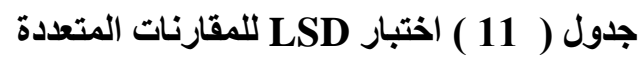

\begin{tabular}{|c|c|c|c|c|c|}
\hline التصميم الخامس = 7.021 & التصميم الرابع & التصميم الثالث 19.655 & التصميم الثاني & التصميم الأول = 13.778 & الجاتب الجمالي \\
\hline & & & & - & التصميم الأول \\
\hline & & & - & $* * 4.302$ & التصميم الثاني \\
\hline & & - & 1.575 & $* * 5.877$ & التصميم الثالث \\
\hline & - & $* * 9.083$ & $* * 7.508$ & $* * 3.206$ & التصميم الرابع \\
\hline- & $* * 3.550$ & $* * 12.633$ & $* * 11.058$ & $* * 6.756$ & التصميم الخامس \\
\hline
\end{tabular}

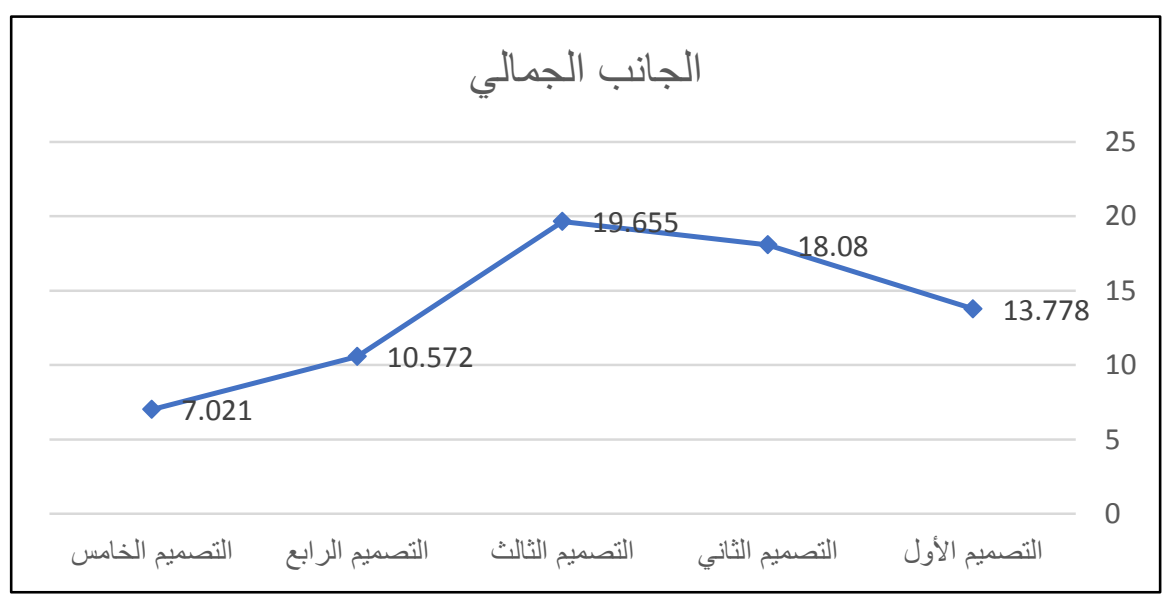




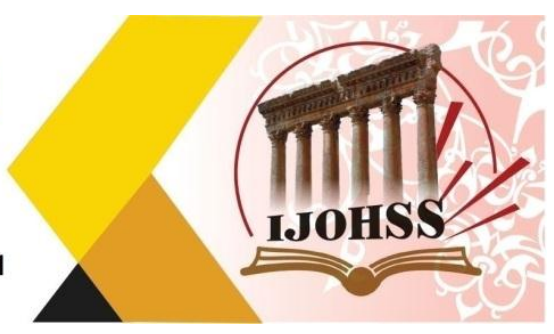

شكل ( 2 ) يوضح متوسط درجات التصميمات الخمس في تحقيق الجانب الجمالي وفقا لميول المختصين

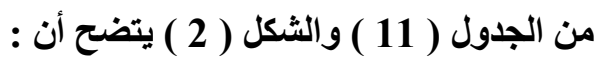

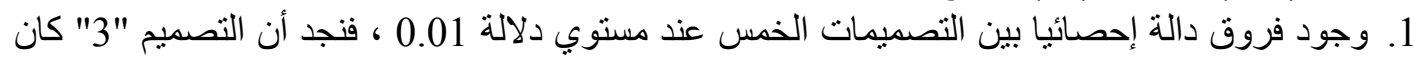

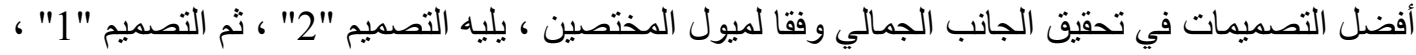

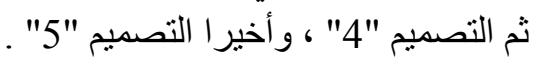

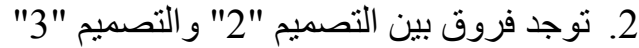

المجموعة الثالثة : التصميمات المطرزة على مكمل ملبسي (الكمامة)

جدول (12) تحليل التباين لمتوسط درجات التصميمات

\begin{tabular}{|c|c|c|c|c|c|}
\hline الدلالة & قيمة (ف) & درجات الحرية & متوسط المربعات & مجموع المربعات & الجاتب الجمالي \\
\hline \multirow{3}{*}{$\begin{array}{c}0.01 \\
\text { دال } \\
\end{array}$} & \multirow{2}{*}{40.592} & 4 & 254.380 & 1017.519 & بين المجموعات \\
\hline & & 45 & 6.267 & 282.001 & داخل المجموعات \\
\hline & & 49 & & 1299.520 & المجموع \\
\hline
\end{tabular}

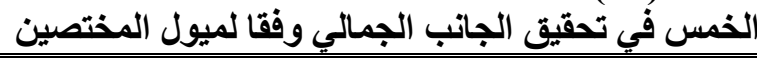

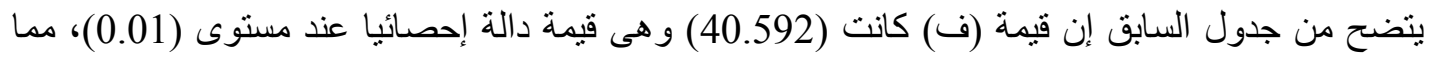

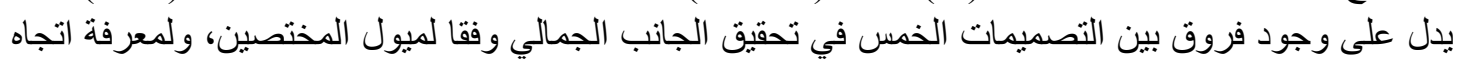

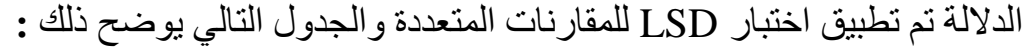

\begin{tabular}{|c|c|c|c|c|c|}
\hline التص = 17.290 & التصميم الرابع 19.569 التصع & التصميم الثالث 14.360. & $\begin{array}{c}\text { التصميم الثاني } 6.400 \\
\end{array}$ & م= التصميم الأول 11.304 & الجانب الجمالي \\
\hline & & & & - & التصميم الأول \\
\hline & & & - & $* * 4.904$ & التصميم الثاني \\
\hline & & - & $* * 7.960$ & $* * 3.056$ & التصميم الثالث \\
\hline & - & $* * 5.209$ & $* * 13.169$ & $* * 8.265$ & التصميم الرابع \\
\hline - & $* 2.279$ & *2.930 & $* * 10.890$ & $* 55.986$ & التصميم الخامس \\
\hline
\end{tabular}

جدول (13) اختبار LSD للمقارنات المتعددة 

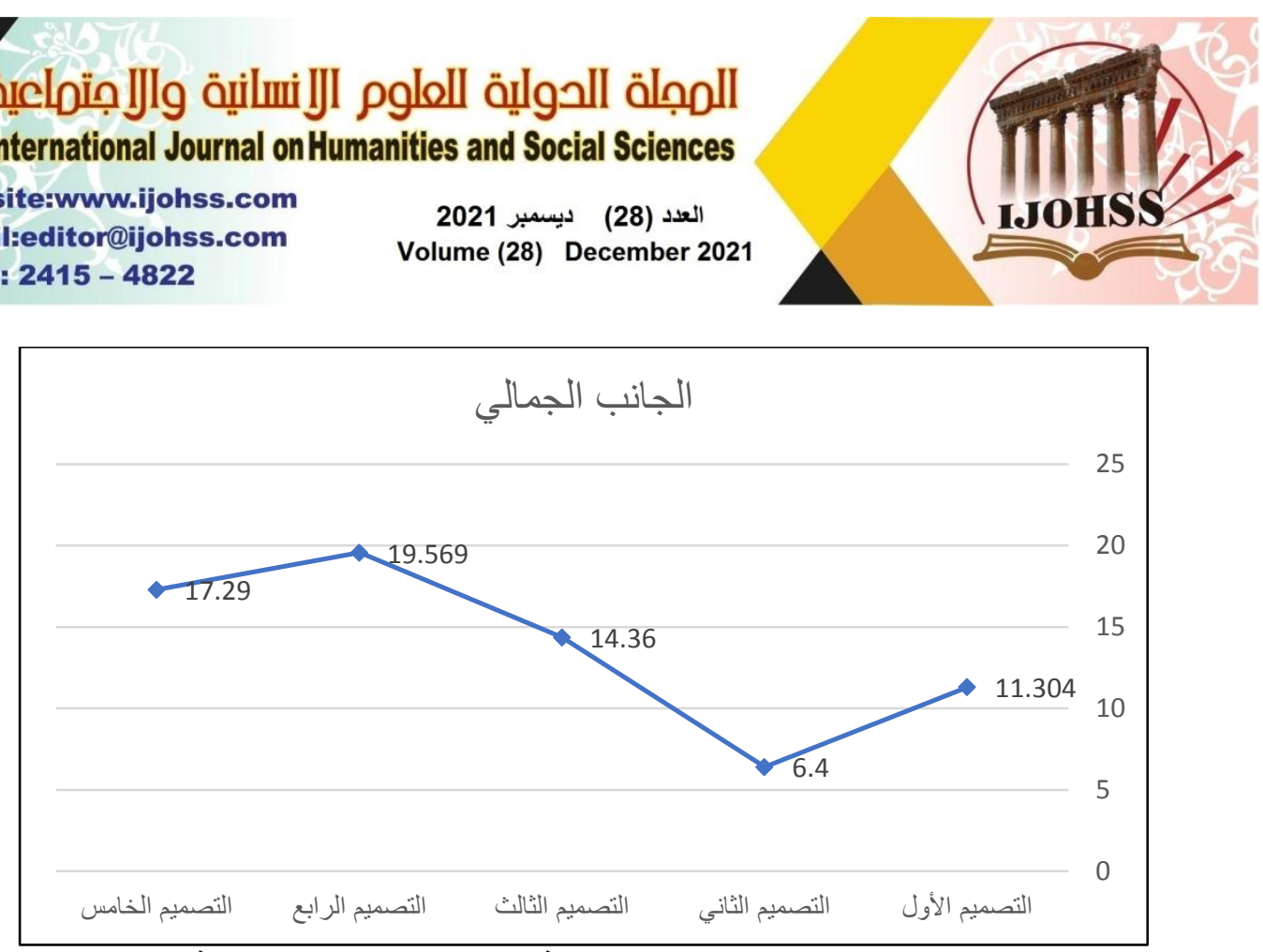

شكل (3) يوضح متوسط درجات التصميمات الخمس في تحقيق الجانب الجمالي وفقا لميول المختصين

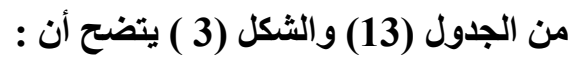

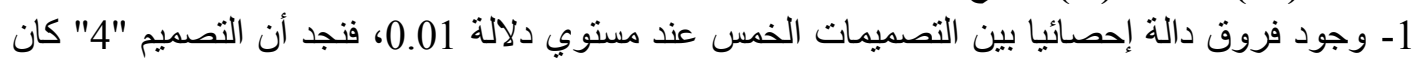

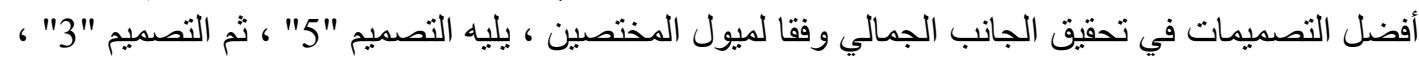

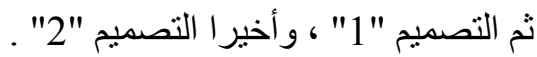

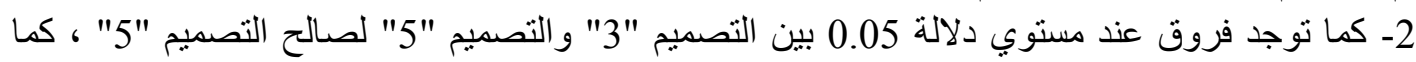

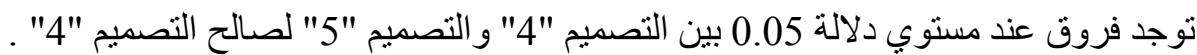
الفرض الثاني: توجد فروق ذات دلالة إحصائية بين التصميمات الخمس في تحقيق الجانب الوظيفي وفقا لميول

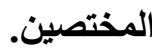
وللتحقق من هذا الفرض نم حساب تحليل التباين لمتوسط درجات التصميمات الخمس في تحقيق الجانب

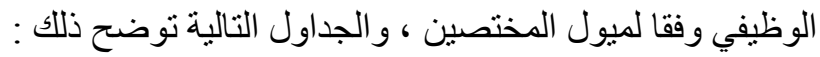
المجموعة الأولى : التصميمات المطرزة على مكمل ملبسي (حزام) جدول ( 14) تحليل التباين لمتوسط درجات التصميمات الخمس في تحقيق الجاتب الوظيفي وفقا لأراء المتخصصين

\begin{tabular}{|c|c|c|c|c|c|}
\hline الدلالة & قيمة (ف) & لدرجات & متوسط المربعات & مجموع المربعات & الجاتب الوظيفي \\
\hline \multirow{3}{*}{0.010} & \multirow{2}{*}{53.030} & 4 & 215.693 & 862.771 & بين المجموعات \\
\hline & & 45 & 4.067 & 183.031 & داخل المجموعات \\
\hline & & 49 & & 1045.802 & المجموع \\
\hline
\end{tabular}

يتضح من جدول السابق إن قيمة (ف) كانت (53.030) وهى قيمة دالة إحصائيا عند مستوى (0.01) ، مما

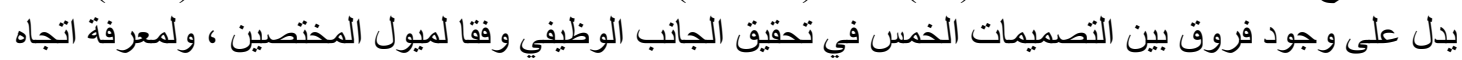
الدلالة تم تطبيق اختبار LSD للمقارنات المتعددة والجدول التالي يوضح ذللك : لالت التين

جدول ( 15 ) اختبار LSD للمقارنات المتعددة

\begin{tabular}{|c|c|c|c|c|c|}
\hline التصميم الخامس & م = التصميم الرابع 7.164 & التصميم الثالث 18.125 & التصميم الثاني & التصميم الأول & الجانب الوظيفي \\
\hline
\end{tabular}




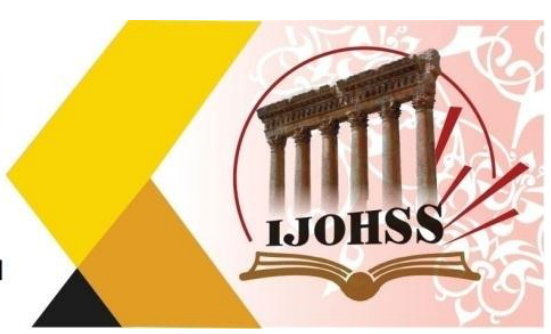

\begin{tabular}{|c|c|c|c|c|c|}
\hline & & & & - & التصميم الأول \\
\hline & & & - & $* * 9.572$ & التصميم الثاني \\
\hline & & - & 1.668 & $* * 7.904$ & التصميم الثالث \\
\hline & - & $* * 10.961$ & $* * 12.629$ & $* * 3.057$ & التصميم الرابع \\
\hline - & $* * 6.292$ & $* * 4.669$ & $* * 6.337$ & $* * 3.235$ & التصميم الخامس \\
\hline
\end{tabular}

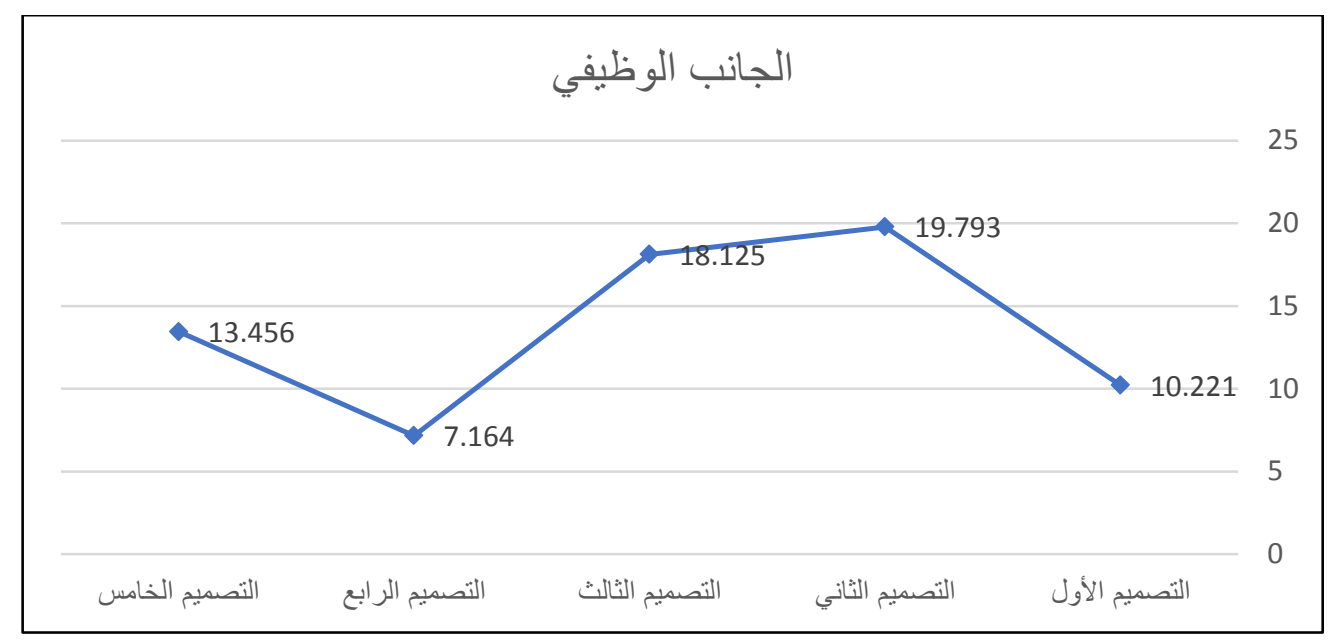

ثكل ( 4 ) يوضح متوسط درجات التصميمات الخمس في تحقيق الجاتب الوظيفي وفقا لميول المختصين

$$
\text { من الجدول ( } 15 \text { ) والثكل (4 ) يتضح أن : }
$$

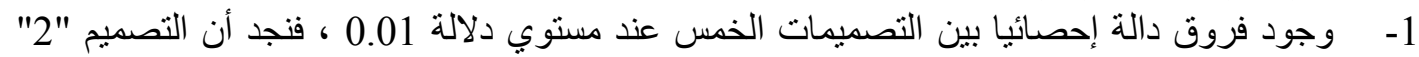

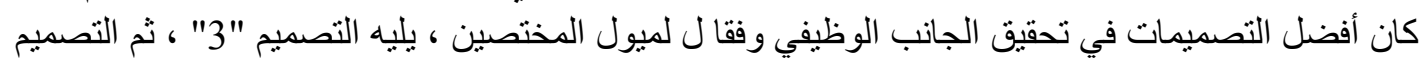

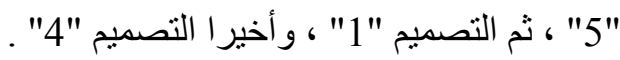

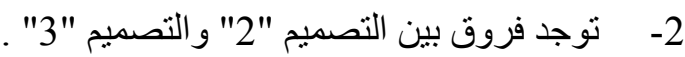
المجموعة الثانية : التصميمات المطرزة على مكمل ملبسي (الثال)

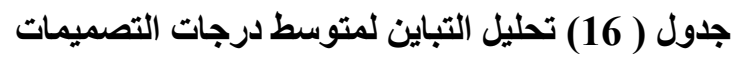

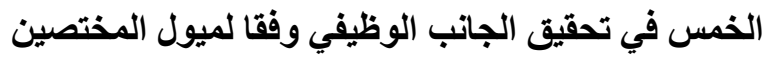

\begin{tabular}{|c|c|c|c|c|c|}
\hline الدلالة & قيمة (ف) & درجات الحرية & متوسط المربعات & مجموع المربعات & الجاتب الوظيفي \\
\hline \multirow{2}{*}{0.010} & \multirow{2}{*}{34.520} & 4 & 279.461 & 1117.845 & بين المجموعات \\
\hline & & 45 & 8.096 & 364.304 & داخل المجموعات \\
\hline & & 49 & & 1482.149 & المجموع \\
\hline
\end{tabular}

يتضح من جدول السابق إن قيمة (ف) كانت (34.520) و هى قيمة دالة إحصائيا عند مستوى (0.01) ، مما

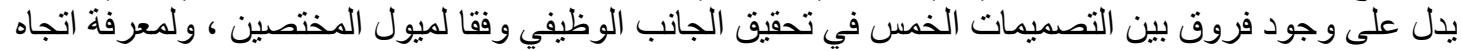

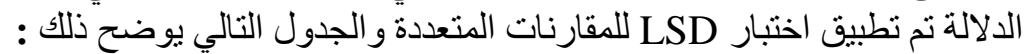

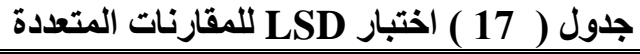

\begin{tabular}{|c|c|c|c|c|c|}
\hline التص = 16.462 التصميم & التصميم الرابع 7.675 & م = التصميم الثالث 19.949 & التصميم الثاني & التصميم الأول 10.404 & الجاتب الوظيفي \\
\hline & & & & - & التصميم الأول \\
\hline
\end{tabular}




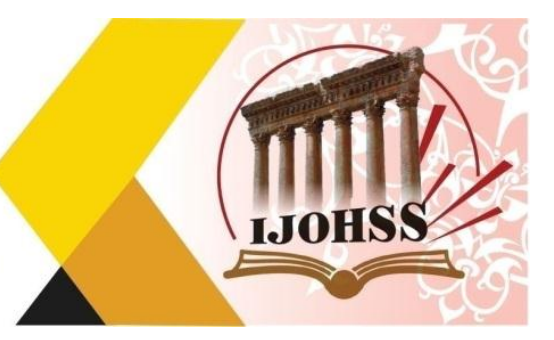

\begin{tabular}{|c|c|c|c|c|c|}
\hline & & & - & $* * 3.574$ & التصميم الثاني \\
\hline & & - & $* 55.971$ & $* \% 9.545$ & التصميم الثالث \\
\hline & - & $* * 12.274$ & $* * 6.303$ & $* 2.729$ & التصميم الرابع \\
\hline - & $* * 8.787$ & $* * 3.487$ & $* 2.484$ & $* * 6.058$ & التصميم الخامس \\
\hline
\end{tabular}

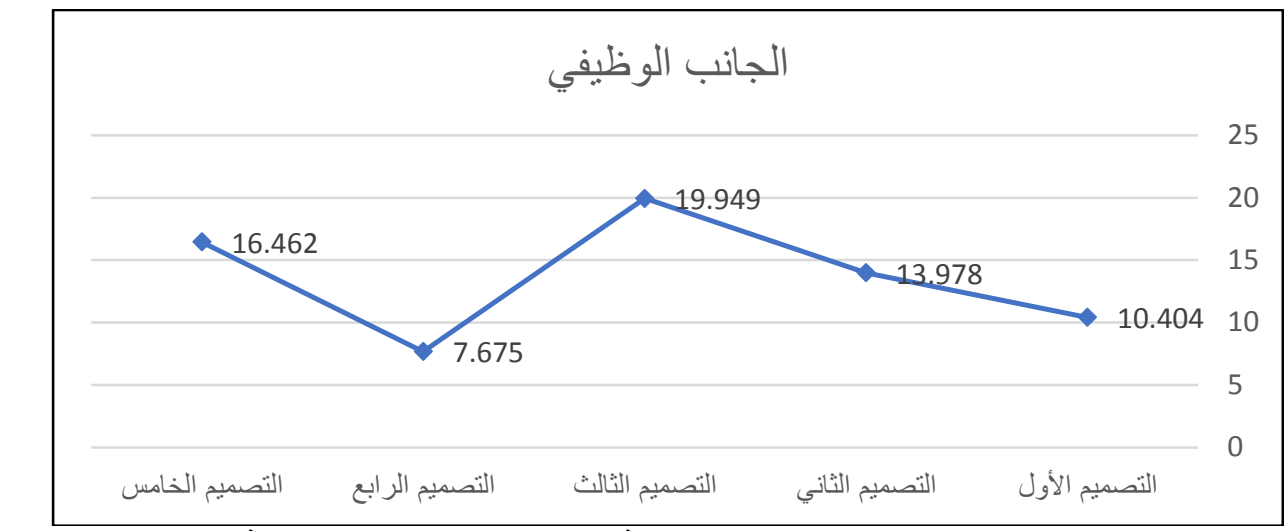

شكل ( 5 ) يوضح متوسط درجات التصميمات الخمس في تحقيق الجاتب الوظيفي وفقا لميول المختصين

$$
\text { من الجدول ( 17) والثكل ( } 5 \text { ) ميتضح أن : }
$$

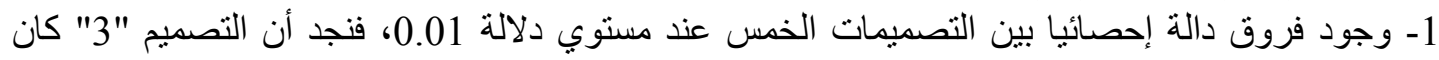

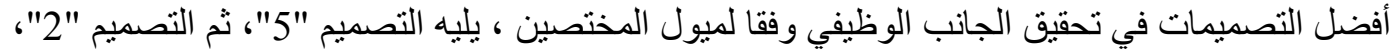

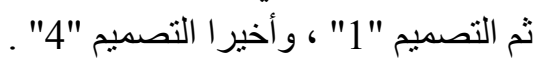

2- كما توجد فروق عند مستوي دلالة 0.05 بين التصميم "1" و التصميم "4" لصالح التصميم "1"، كما توجد

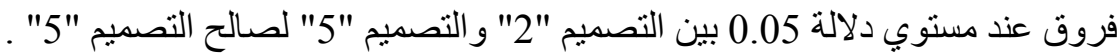

المجموعة الثالثة: التصميمات المطرزة على مكمل ملبسي (الكمامـة)

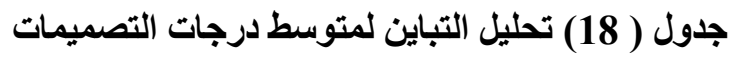

\begin{tabular}{|c|c|c|c|c|c|}
\hline الالالة & قيمة (ف) & درجات الحرية & متوسط المربعات & مجموع المربعات & الجانب الوظيفي \\
\hline \multirow{3}{*}{0.0101} & \multirow{2}{*}{27.264} & 4 & 228.078 & 912.312 & بين المجموعات \\
\hline & & 45 & 8.366 & 376.453 & داخل المجموعات \\
\hline & & 49 & & 1288.765 & المجموع \\
\hline
\end{tabular}

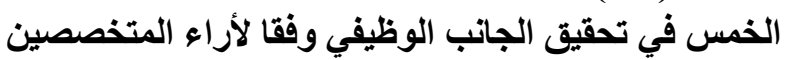

يتضح من جدول السابق إن قيمة ( ف) كانت (27.264) و هى قيمة دالة إحصائيا عند مستوى (0.01) ، مما

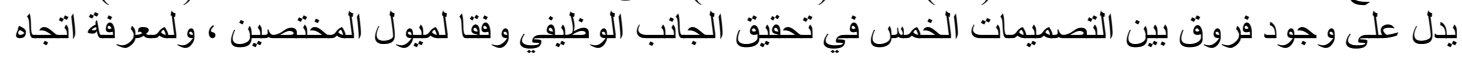

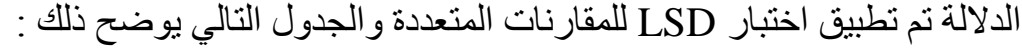

\begin{tabular}{|c|c|c|c|c|c|}
\hline م = التصميم الخامس 15.309 & م التصميم & م = التصميم الثالث 15.724 & م = التصميم الثاني & م = التصميم الأول 10.230 & الجاتب الوظيفي \\
\hline & & & & - & التصميم الأول \\
\hline & & & - & $* \% 9.254$ & التصميم الثاني \\
\hline
\end{tabular}
جدول ( 19 ) اختبار LSD للمقارنات المتعددة 


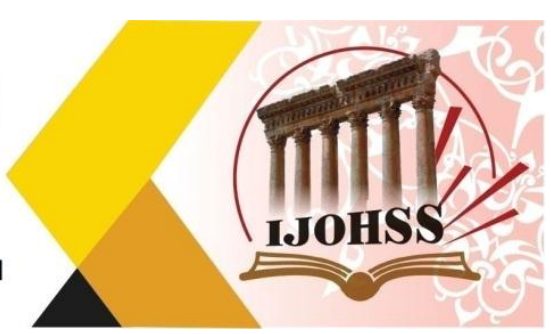

\begin{tabular}{|c|c|c|c|c|c|}
\hline & & - & $* * 3.760$ & $* * 5.494$ & التصميم الثالث \\
\hline & - & $* \% 9.030$ & $* * 12.790$ & $* * 3.536$ & التصميم الرابع \\
\hline- & $* * 8.615$ & 0.415 & $* * 4.175$ & $* * 5.079$ & التصميم الخامس \\
\hline
\end{tabular}

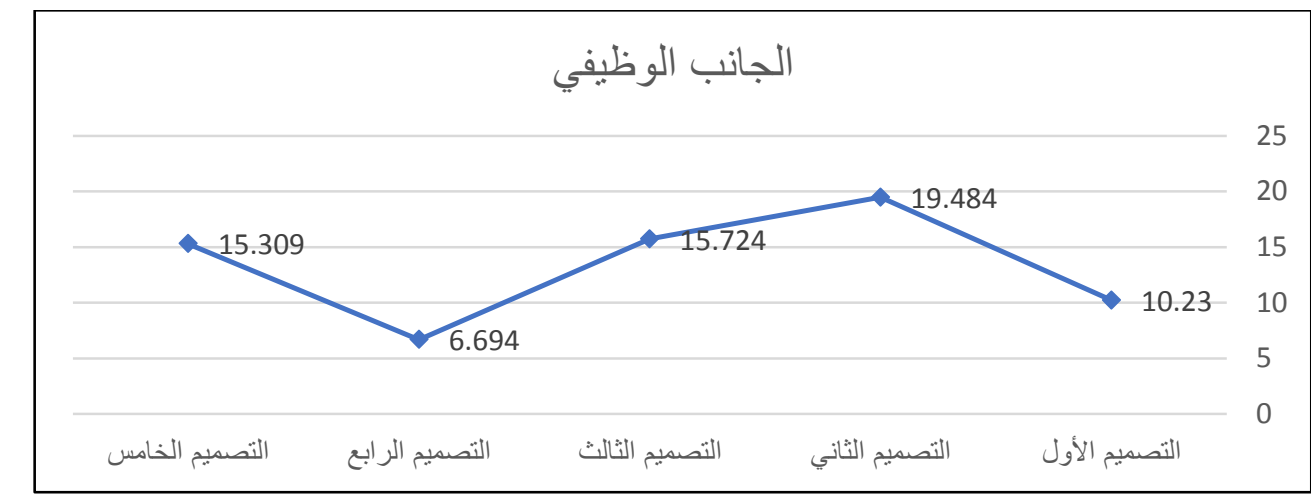

شكل ( 6 ) يوضح متوسط درجات التصميمات الخمس في تحقيق الجانب الوظيفي وفقا ل لميول المختصين

$$
\text { من الجدول ( 19) والثكل ( } 19 \text { ) يتضح أن : }
$$

1- وجود فروق دالة إحصائبا بين التصميمات الخمس عند مستوي دلالة 0.01 ، فنجد أن التصميم "2" كان ،

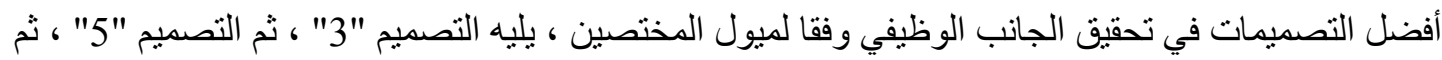

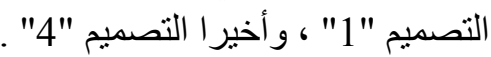

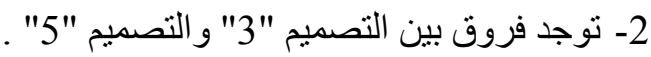

الفرض الثالث : توجد فروق ذات دلالة إحصائية بين التصميمات الخمس وفقا لميول المستهالكات

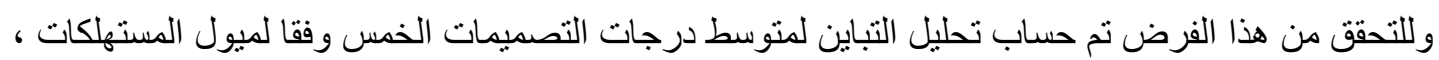

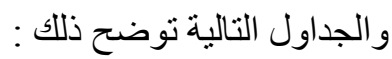

المجموعة الأولى : التصميمات المطرزة تولح دلى مكمل ملبسي (حزام)

\begin{tabular}{|c|c|c|c|c|c|}
\hline الدلالة & قيمة (ف) & الرجات & متوسط المربعات & مجموع المربعات & "المجتوع الكلي" \\
\hline \multirow{3}{*}{0.01} & \multirow{2}{*}{48.674} & 4 & 2915.348 & 11661.393 & بين المجموعات \\
\hline & & 195 & 59.896 & 11679.717 & داخل المجموعات \\
\hline & & 199 & & 23341.110 & المجموع \\
\hline
\end{tabular}
جدول ( 20) تحليل التباين لمتوسط درجات التصميمات الخمس وفقات لميول مليول المستهلكات

يتضح من جدول السابق إن قيمة (ف) كانت (48.674) و هى قيمة دالة إحصائيا عند مستوى (0.01) ، مما

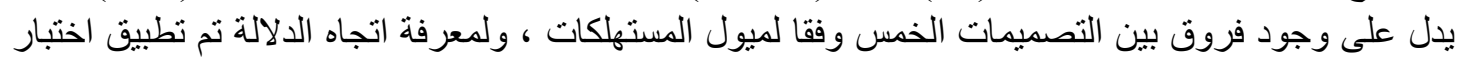

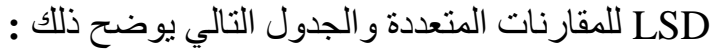

\begin{tabular}{|c|c|c|c|c|c|}
\hline التص = 54.307 الخامس & م = التصميم الرابع & م = التصميم الثالث 40.212 & التصميم الثاني & م= التصميم الأول & "المجموعلكات" الكلي \\
\hline & & & & - & التصميم الأول \\
\hline
\end{tabular}
جدول ( 21 ) اختبار LSD للمقارنات المتعددة 


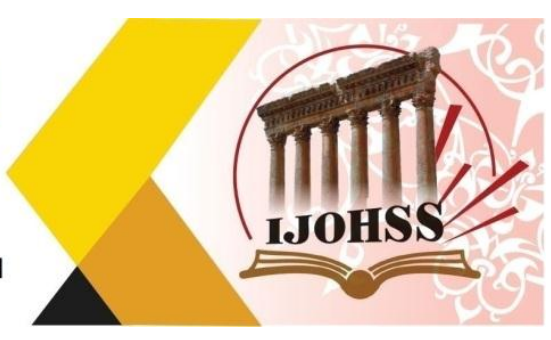

\begin{tabular}{|c|c|c|c|c|c|}
\hline & & & - & $* * 14.723$ & التصميم الثاني \\
\hline & & - & $* 4.674$ & $* * 19.397$ & التصميم الثالث \\
\hline & - & $* * 10.609$ & $* * 5.935$ & $* * 8.788$ & التصميم الرابع \\
\hline - & $* 3.485$ & $* * 14.094$ & $* * 9.420$ & $* * 5.303$ & التصميم الخامس \\
\hline
\end{tabular}

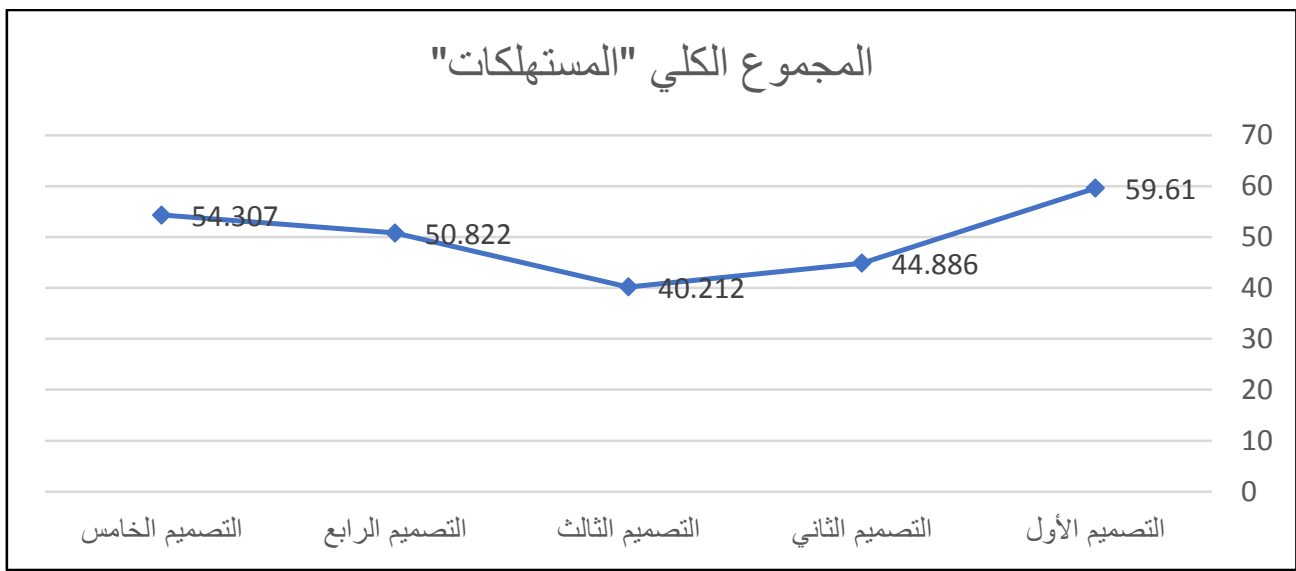

شكل ( 7 ) يوضح متوسط درجات التصميمات الخمس وفقا لميول المستهكات

من الجدول (21) والثكل (7) يتضح أن:

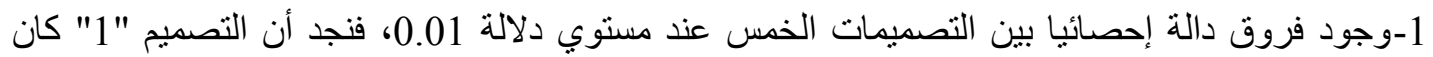

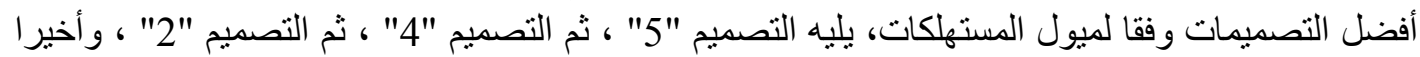

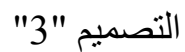

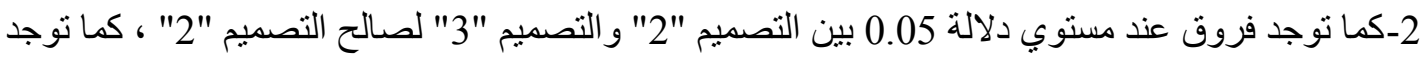

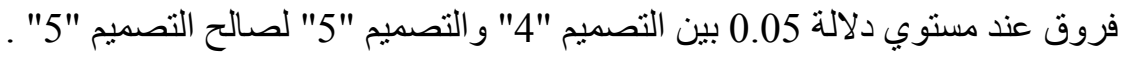

المجموعة الثانية : التصميمات المطرزة على مكمل ملبسي (الثال)

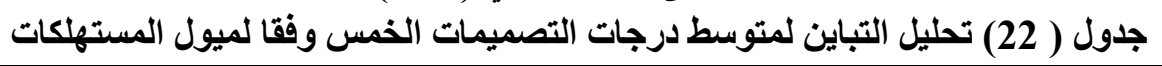

\begin{tabular}{|c|c|c|c|c|c|}
\hline الدلالة الد & قيمة (ف) & درجات الحرية & متوسط المربعات & مجموع المربعات & "المجموع الكلي \\
\hline \multirow{3}{*}{0.01} & \multirow[b]{2}{*}{35.179} & 4 & 4153.712 & 16614.849 & بين المجموعات \\
\hline & & 195 & 118.072 & 23024.040 & 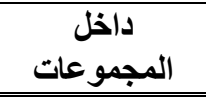 \\
\hline & & 199 & & 39638.889 & المجموع \\
\hline
\end{tabular}

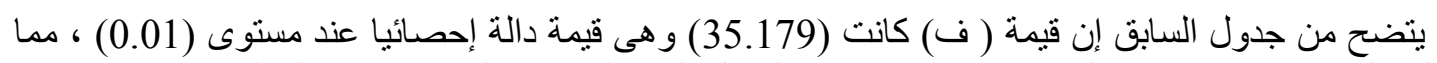

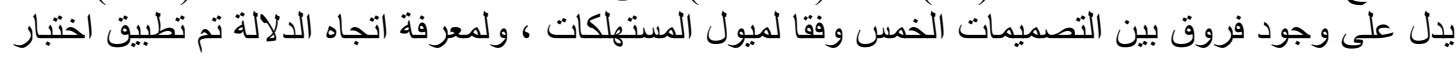

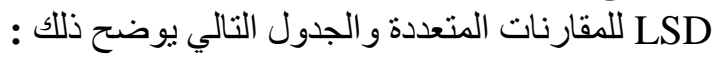
جدول (23) اختبار LSD للمقارنات المتعددة

\begin{tabular}{|c|c|c|c|c|c|}
\hline التصميم الخامس & م = التصميم الرابع & م= التصميم الثالث & م= التصميم الثاني & م= التصميم الأول & "المستوعلكات" الكلي \\
\hline & & & & - & التصميم الأول \\
\hline & & & - & $* * 13.271$ & التصميم الثاني \\
\hline
\end{tabular}




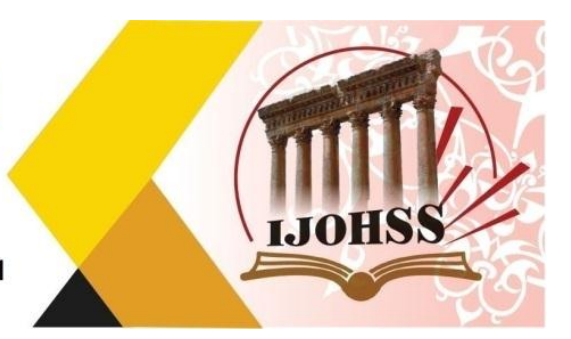

\begin{tabular}{|c|c|c|c|c|c|}
\hline & & - & $* * 24.680$ & $* * 11.408$ & التصميم الثالث \\
\hline & - & $* * 5.522$ & $* * 19.158$ & $* * 5.886$ & التصميم الرابع \\
\hline- & $* * 13.630$ & $* * 19.152$ & $* * 5.528$ & $* * 7.743$ & التصميم الخامس \\
\hline
\end{tabular}

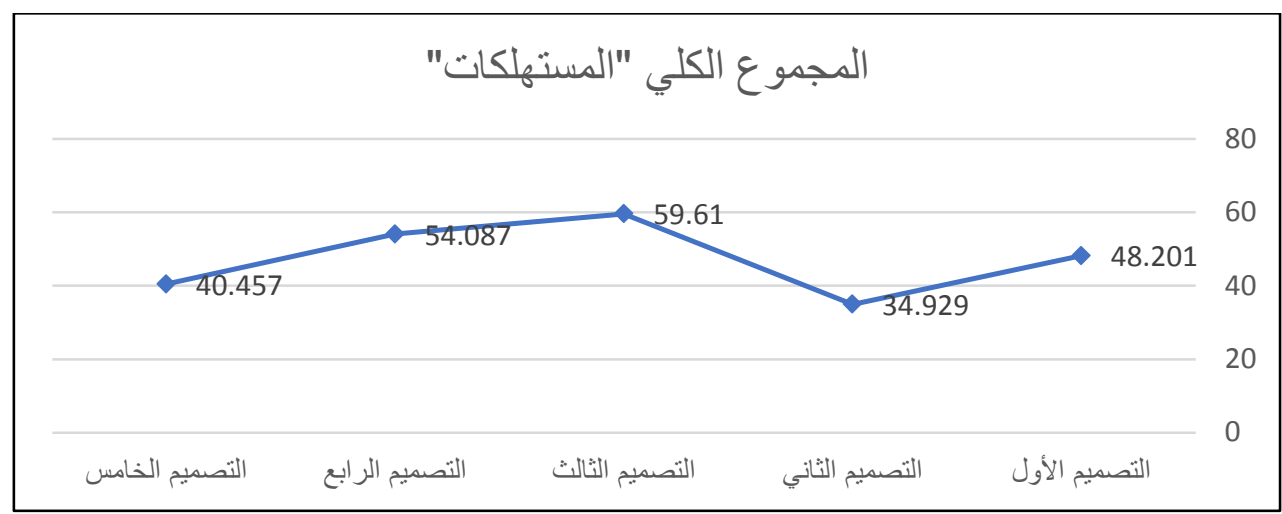

شكل ( 8 ) يوضح متوسط درجات التصميمات الخمس وفقا لميول المستهأكات

من الجدول ( 23) و الثكل ( 8 ) يتضح وجود فروق دالة إحصائيا بين التصميمات الخمس عند مستوبي دلالية 0.01 ، فنجد أن التصميم "3" كان أفضل التصميمات وفقا لميول المستهلكات ، يليه التصميم "4" ، ، ثم التصميم

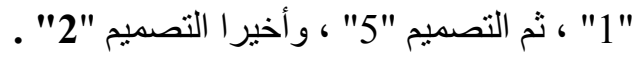

المجموعة الثالثة: التصميمات المطرزة على مكمل ملبسي (الكمامـة)

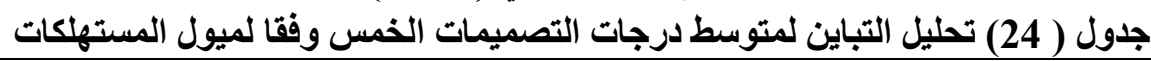

\begin{tabular}{|c|c|c|c|c|c|}
\hline الدلالة الد & قيمة (ف) & درجات الحرية & متوسط المربعات & مجموع المربعات & "المجتوع الكلكات" \\
\hline \multirow{3}{*}{0.01 دال } & \multirow{2}{*}{50.644} & 4 & 3641.162 & 14564.649 & بين المجموعات \\
\hline & & 195 & 71.897 & 14019.818 & داخل المجموعات \\
\hline & & 199 & & 28584.467 & المجموع \\
\hline
\end{tabular}

يتضح من جدول السابق إن قيمة (ف) كانت (50.644) و هي قيمة دالة إحصائيا عند مستوى (0.01)، مما يدل على وجود فروق بين التصميمات الخمس وفقا لميول المستهلكات، ولمعرفة اتجاه الدلالة نم تطبيق اختبار

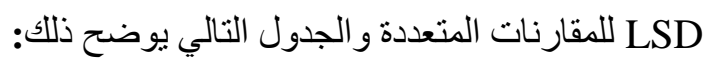
جلول LSD المقارنات المتعددة

\begin{tabular}{|c|c|c|c|c|c|}
\hline التصميم الخامس & $\begin{array}{l}\text { التصميم = الرابع } 51.015 \\
\end{array}$ & 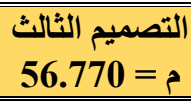 & التصميم الثاني 33.300 التصيم & التصميم الأول & "المجتوع الكات" \\
\hline & & & & - & التصميم الأول \\
\hline & & & - & $* * 9.225$ & التصميم الثاني \\
\hline & & - & $* * 23.470$ & $* * 14.245$ & التصميم الثالثَ \\
\hline & - & $* * 5.755$ & $* * 17.715$ & $* * 8.490$ & التصميم الرابع \\
\hline - & $* * 13.252$ & **19.007 & $* 4.462$ & $* 4.762$ & التصميم الخامس \\
\hline
\end{tabular}



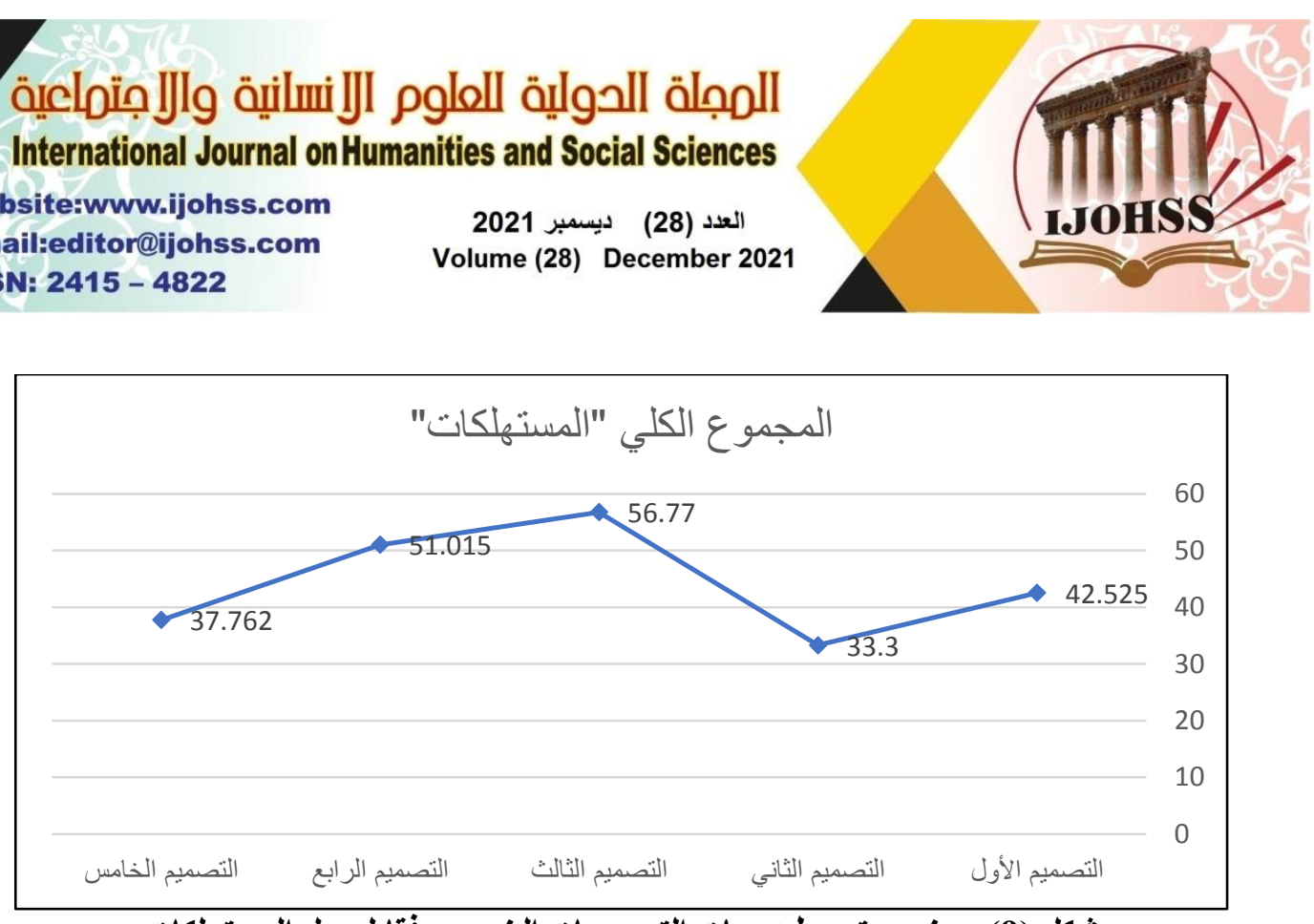

شكل (9) يوضتح متوسط درجات التصميمات الخمس وفقا لميول المستهلكات

من الجدول (25) والثكل (9) يتضح أن:

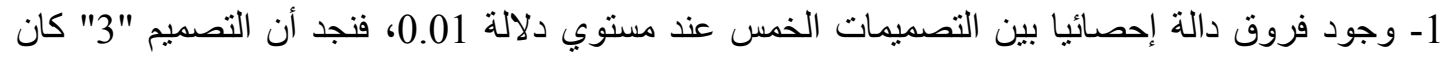

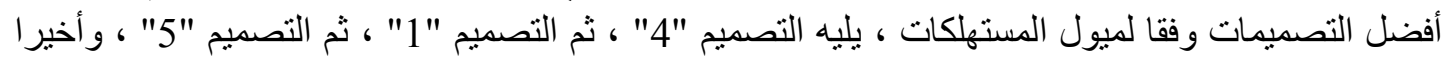

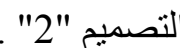

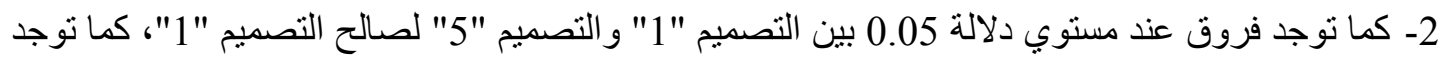

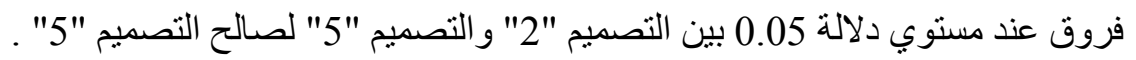

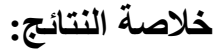
1. ان زخارف التراث السعودي المطرزة اضافة قيمة جمالية ووظيفية على مكملات الملابس.

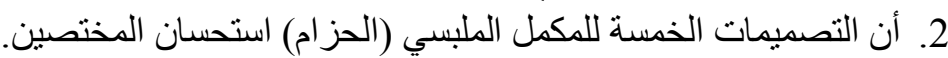

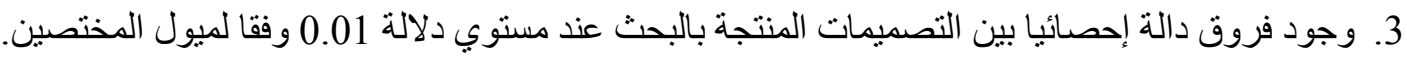

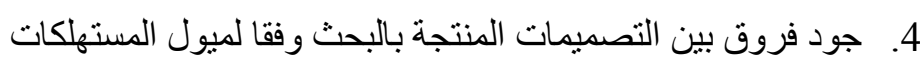

التوصيات

1. المساهمة في الحفاظ على التراث السعودي بجميع أشكاله وتتو عهد وابر ازه من خلال الملابس ومكملاتها في المحافل المحلية و العالمية.

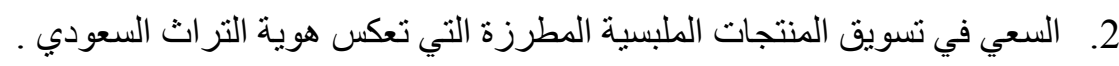

3. الحث في عمل دراسات تطبيقية مماتلة تبرز جماليات الموروث تهون الحضاري و الملبسي بفن معاصر حديث.

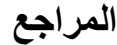

1.

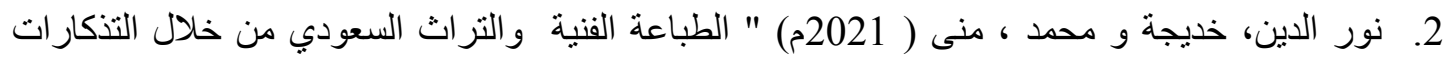

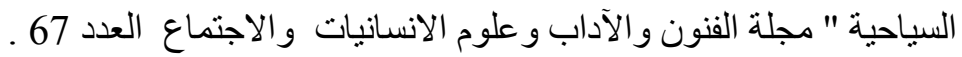

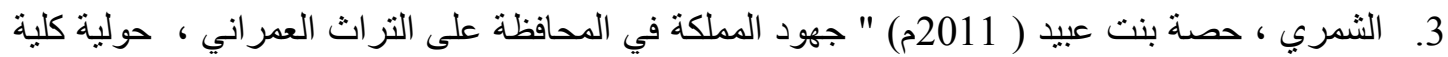

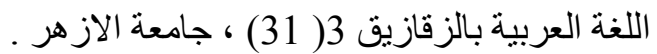

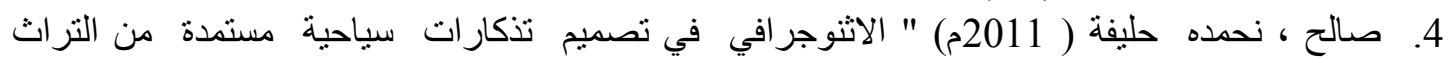
السعودي كمدخل للإسهام في التتمية البشرية ، مجلة التربية ، جامعة الازهر : القاهرة 


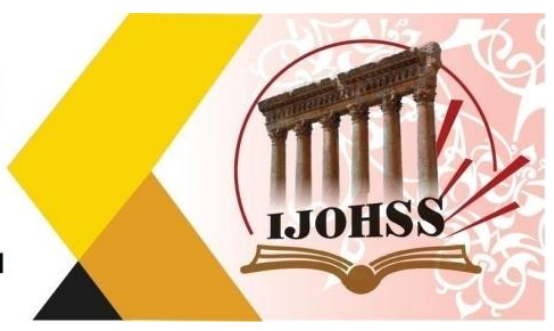

5. رشيدي، سلوى أحمد (2021م) " التراث ودورة في إثراء التصميم الإبداعي للخزاف المعاصر " مجلة

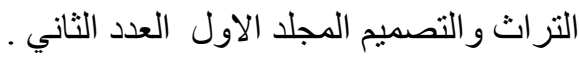

6. القعوان ، صالح و الابرش ، محمود (2019م) آليات تعزيز الهوية الوطنية " مجلة السراج في التربية

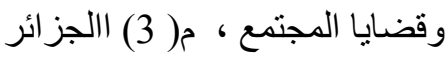

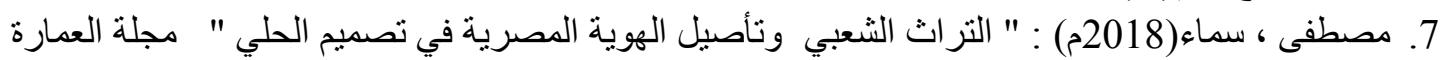

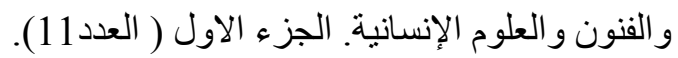

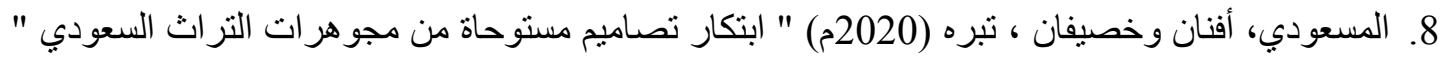

مجلة التصميم الدولية المجلد (11) العدد (4).

9. هلال ، سعاد و النعيمي ، ندى (11) (2015م) " تصاميم الملابس النسائية و علاقتها بالإكسسوار اتل " مجلة كلية

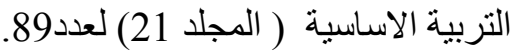

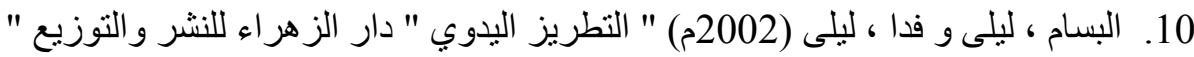

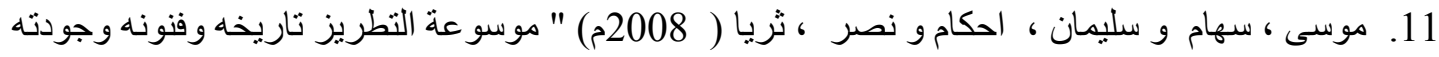

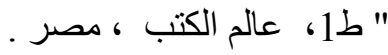

12. علي، لمياء (2008م) " ابتكار تصميمات مقتبسة من الزخارف في العصر العثماني وتوظيفها لإثراء تكنولوجيا التصميم الزخرفي و التطريز باستخدام الحاسب الآلي " رسالة دكتور الزها كلية الاقتصاد المنزلي،

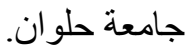

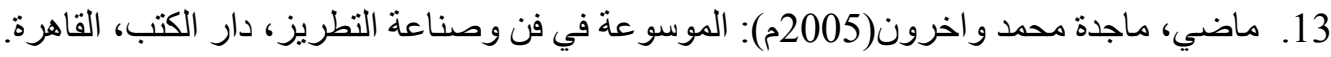
14. نجم، و لاء (2019م):" تصميم ملصق اعلاني سياحي عن واحة الاحساء بالمنطقة الثرقية "مجلة بحوث فئرة التربية النو عية، جامعة المنصور. 15. نبوي ، اسماء (2018)"جماليات زخارف الإنة الابواب النجدية بن تأصيل الهوية العربية و التفكير الابداعي "

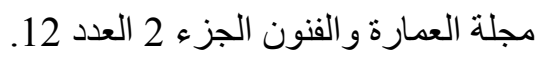

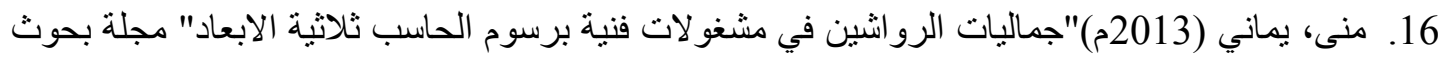

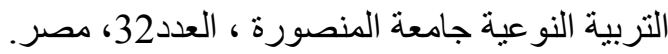

